\title{
Internal ammonium excess induces ROS- mediated reactions and causes carbon scarcity in rice
}

Shunying Yang ${ }^{1}$, Dongli Hao', Man Jin ${ }^{1,2}$, Yi Li ${ }^{1,2}$, Zengtai Liu ${ }^{1,2}$, Yanan Huang ${ }^{1,2}$, Tianxiang Chen ${ }^{1,2}$ and Yanhua Su ${ }^{1 *}$

\begin{abstract}
Background: Overuse of nitrogen fertilizers is often a major practice to ensure sufficient nitrogen demand of highyielding rice, leading to persistent $\mathrm{NH}_{4}{ }^{+}$excess in the plant. However, this excessive portion of nitrogen nutrient does not correspond to further increase in grain yields. For finding out the main constraints related to this phenomenon, the performance of $\mathrm{NH}_{4}{ }^{+}$excess in rice plant needs to be clearly addressed beyond the well-defined root growth adjustment. The present work isolates an acute $\mathrm{NH}_{4}{ }^{+}$excess condition in rice plant from causing any measurable growth change and analyses the initial performance of such internal $\mathrm{NH}_{4}^{+}$excess.

Results: We demonstrate that the acute internal $\mathrm{NH}_{4}{ }^{+}$excess in rice plant accompanies readily with a burst of reactive oxygen species (ROS) and initiates the downstream reactions. At the headstream of carbon production, photon caption genes and the activity of primary $\mathrm{CO}_{2}$ fixation enzymes (Rubisco) are evidently suppressed, indicating a reduction in photosynthetic carbon income. Next, the vigorous induction of glutathione transferase (GST) genes and enzyme activities along with the rise of glutathione (GSH) production suggest the activation of GSH cycling for ROS cleavage. Third, as indicated by strong induction of glycolysis / glycogen breakdown related genes in shoots, carbohydrate metabolisms are redirected to enhance the production of energy and carbon skeletons for the cost of ROS scavenging. As the result of the development of these defensive reactions, a carbon scarcity would accumulatively occur and lead to a growth inhibition. Finally, a sucrose feeding cancels the ROS burst, restores the activity of Rubisco and alleviates the demand for the activation of GSH cycling.
\end{abstract}

Conclusion: Our results demonstrate that acute $\mathrm{NH}_{4}{ }^{+}$excess accompanies with a spontaneous ROS burst and causes carbon scarcity in rice plant. Therefore, under overuse of $\mathrm{N}$ fertilizers carbon scarcity is probably a major constraint in rice plant that limits the performance of nitrogen.

Keywords: Rice, $\mathrm{NH}_{4}{ }^{+}$excess, ROS, GSH cycle, Carbon scarcity, Sucrose feeding

\section{Background}

Nitrogen $(\mathrm{N})$ limitation is a leading constraint to the grain yield of rice $[1,2]$. Leaf $\mathrm{N}$ accounts for the largest $\mathrm{N}$ sink of rice plant, ca. $80 \%$ of which is distributed in

\footnotetext{
* Correspondence: yhsu@issas.ac.cn

${ }^{1}$ State Key Laboratory of Soil and Sustainable Agriculture, Institute of Soil Science, Chinese Academy of Sciences, No. 71, East Beijing Road, Nanjing 210008, China

Full list of author information is available at the end of the article
}

the chloroplast and stored as Ribulose-1,5-bisphosphate carboxylase / oxygenases (Rubisco), the primary carbon fixation enzymes of $C_{3}$ plants [3]. Photosynthesis is tightly correlated to leaf $\mathrm{N}$ content [4], and more than $80 \%$ of grain $\mathrm{N}$ is derived from leaves in rice [5]. Hence, insufficient leaf $\mathrm{N}$ storage will lead to reduction of photosynthetic carbon fixation efficiency and is therefore

(c) The Author(s). 2020 Open Access This article is licensed under a Creative Commons Attribution 4.0 International License, which permits use, sharing, adaptation, distribution and reproduction in any medium or format, as long as you give appropriate credit to the original author(s) and the source, provide a link to the Creative Commons licence, and indicate if changes were made. The images or other third party material in this article are included in the article's Creative Commons licence, unless indicated otherwise in a credit line to the material. If material is not included in the article's Creative Commons licence and your intended use is not permitted by statutory regulation or exceeds the permitted use, you will need to obtain permission directly from the copyright holder. To view a copy of this licence, visit http://creativecommons.org/licenses/by/4.0/ The Creative Commons Public Domain Dedication waiver (http://creativecommons.org/publicdomain/zero/1.0/) applies to the data made available in this article, unless otherwise stated in a credit line to the data. 
considered as a major limitation to biomass and grain production of cereal ecosystems [6-9].

To sustain the strong and persistent $\mathrm{N}$ demand for higher grain yield of rice (6.4 $\mathrm{tha}^{-1}$ or above), the average $\mathrm{N}$ input is normally over $180 \mathrm{~kg} \mathrm{ha}^{-1}$ in China [10]. In the high-yielding rice farming areas, the $\mathrm{N}$ input can even reach to $300 \mathrm{~kg} \mathrm{ha}^{-1}$ and this is particularly the case for recent super-hybrid rice cultivars that achieve as high as $>10 \mathrm{t} \mathrm{ha}^{-1}$ of grain yields [11]. In soils, applied $\mathrm{N}$ fertilizers (e.g. urea form accounted for the majority of current $\mathrm{N}$ fertilizers) are rapidly converted to ammonium with the potent reactions of ureases. In rice paddy soils, ca. $70-80 \%$ of the growth period is water flooded, causing an anaerobic environment that largely prevents the process of nitrification. Therefore, $\mathrm{NH}_{4}{ }^{+}$is the major form of nitrogen available to rice plant. Thus efficient dealing with $\mathrm{NH}_{4}{ }^{+}$is a most important concern in rice. However, recent results show that overuse of $\mathrm{N}$ fertilizers strengthens excessive $\mathrm{NH}_{4}{ }^{+}$accumulation in rice plant that does not correspond to further increase in grain yields [12]. Therefore, low efficiencies of $\mathrm{N}$ utilization and its agronomic benefits are major problems of $\mathrm{N}$ overuse in rice farming. The performance of such redundant portion of $\mathrm{NH}_{4}^{+}$is thus a meaningful issue of investigations.

The most straightforward observation caused by high $\mathrm{NH}_{4}{ }^{+}$over-supply is the strong reduction of root growth. To this respect, significant advances have been achieved centering the insightful molecular mechanisms or pathways that modulate the adjustment of root morphology. In Arabidopsis, root tip contact to high $\mathrm{NH}_{4}{ }^{+}$is essential for triggering the inhibitory growth of primary roots [13]. Whereas leaf contact and accumulation of toxic $\mathrm{NH}_{4}{ }^{+}$impair AUX1-mediated primary polar transport of IAA to the roots thereby inhibit the emergence of lateral roots [14]. In rice, continuous exposure for several days to high $\mathrm{NH}_{4}{ }^{+}$strongly inhibits seminal root elongation then causes a reduction in plant growth [15-19]. Moreover, the mechanisms of $\mathrm{NH}_{4}{ }^{+}$toxicity to plants are considered to result from the accumulative consequences of divergent frustrations such as ion imbalance, intracellular $\mathrm{pH}$ disturbance, carbon limitation, charge/hormone imbalance or oxidative stresses [2024]. In addition, the analysis of Arabidopsis $h s n / v t c ~ m u-$ tants indicates that GDP-mannose pyrophosphorylasesmediated protein $\mathrm{N}$-glycosylation can also participate in the modulation of root elongation under $\mathrm{NH}_{4}{ }^{+}$stresses [25-27]. Moreover, phytohormone signals are reported to interact with $\mathrm{NH}_{4}{ }^{+}$supply and regulate plant metabolism, growth and development [13, 14, 24, 25, 27, 28]. In addition, a number of transcriptome analyses speculate that the redirections of carbohydrate metabolisms, amino acid metabolisms $[19,29]$ in rice plant are responsible for the toxicity of excessive $\mathrm{NH}_{4}{ }^{+}$. To the opposite direction, efforts have also been put to the retrieval of plant from severe stress of $\mathrm{NH}_{4}{ }^{+}$toxicity. For instance, the application of gamma-aminobutyric acid (GABA) alleviates $\mathrm{NH}_{4}{ }^{+}$toxicity through reducing $\mathrm{NH}_{4}{ }^{+}$ accumulation and assimilation capacity for a energy saving [30]. OsPTR6 promotes rice root growth by enhancing OsAMT1 expression and GS activity but at the expense of decreasing nitrogen use efficiency [31]; OsSE5 that encodes the heme-heme oxygenase 1 dedicates to relieving $\mathrm{NH}_{4}^{+}$toxicity by reinforcing antioxidant defense system [18].

In general, the current knowledge on plant responses to $\mathrm{NH}_{4}{ }^{+}$toxicity has focused on the impacts of high $\mathrm{NH}_{4}{ }^{+}$supplied outside to the roots that depends on the occurrence of a measurable phenotype to accumulate for a relatively longer time course. To this respect, 'mixed' influences between specific $\mathrm{NH}_{4}{ }^{+}$stress responses and endogenous changes along the course of plant growth and development seem inevitable. Therefore, to one hand, the initiation of high $\mathrm{NH}_{4}{ }^{+}$stress responses needs to be specifically isolated; to the other hand, the physiological and or molecular performances of $\mathrm{NH}_{4}{ }^{+}$excess retained inside rice plant remain to be addressed independently of a root phenotype.

The previous study implies that the adjustment of carbohydrate metabolisms could be a notable feature in responding $\mathrm{NH}_{4}{ }^{+}$status in rice in a short time period [29]. Environmental stress stimuli such as salinity or drought stresses induce the overproduction of reactive oxygen species (ROS) and promptly trigger oxidative defense responses [32, 33]. As the result, the reduction of photosynthetic $\mathrm{CO}_{2}$ fixation efficiency and redirection of carbohydrate metabolism could speculatively be major causes leading to compromised carbon gain and growth retardance $[32,34]$. Therefore, findings or speculations from classical stress responses provide useful links to uncover the nature of the toxicity of internal $\mathrm{NH}_{4}{ }^{+}$excess that has not been clearly demonstrated.

Based on the above descriptions, the present work aims at isolating the initial reactions and (molecular-) physiological responses of rice plant to the internal $\mathrm{NH}_{4}{ }^{+}$excess stress before the formation of a visible phenotype. For this purpose, an acute method is established allowing drastic $\mathrm{NH}_{4}{ }^{+}$excess within several hours. This is anticipated a problem-solving orientated work that could be practically useful for further understanding the performance of excess $\mathrm{NH}_{4}{ }^{+}$in rice plant caused by overuse of $\mathrm{N}$ fertilizers. By the integration of physiological observation, transcriptomic gene expression analysis and enzyme activity assays, we demonstrate that the activation of the toxic effects of acute $\mathrm{NH}_{4}{ }^{+}$excess is readily initiated by the bursts of reactive oxygen species (ROS) and subsequently leads to damages to the photosynthetic components and causes the headstream 
reduction of the activity of primary $\mathrm{CO}_{2}$ fixation. Meanwhile, elevated ROS in the plant activates GSH cycles for active radical scavenging that requires the redirection of carbohydrate metabolisms for engergization and for providing of carbon skeletons. These downstream reactions strengthen the carbon scarcity in rice plant. Finally, a sucrose feeding effectively alleviates ROS-induced frustrations, supporting that the carbon scarcity is a major constraint of rice plant in dealing with internal $\mathrm{NH}_{4}{ }^{+}$ excess.

\section{Results}

Growth inhibition under high $\mathrm{NH}_{4}{ }^{+}$correlates to an $\mathrm{NH}_{4}{ }^{+}$ excess induced ROS burst in rice seedlings

Under persistent treatment with high $\mathrm{NH}_{4}{ }^{+}(20 \mathrm{mM})$ for $14 \mathrm{~d}$, a significant growth inhibition was observed compared to the control condition $\left(1 \mathrm{mM} \mathrm{NH}_{4}^{+}\right)$ (Fig. 1a). The inhibition was more profound in roots showing a biomass reduction of up to $67 \%$ (Fig. 1a) and the root/shoot ratio was significantly lowered from approximately 0.5 down to 0.2 (Fig. 1b). Meanwhile, 7 and 5 folds higher concentrations of free $\mathrm{NH}_{4}{ }^{+}$were measured in roots and shoots, respectively (Fig. 1c). Nevertheless, the strong inhibition of root growth under high $\mathrm{NH}_{4}{ }^{+}$supplement was a well-defined issue that had attracted numerous investigations. Efforts have be extensively made on the elucidation of molecular mechanisms involved in root architecture adjustments in response to the accumulation of relatively long-term (several days or longer) stress effects impended by high $\mathrm{NH}_{4}{ }^{+}$treatments. Here to reveal early responsive reactions that could be the trigger of the accumulative responses
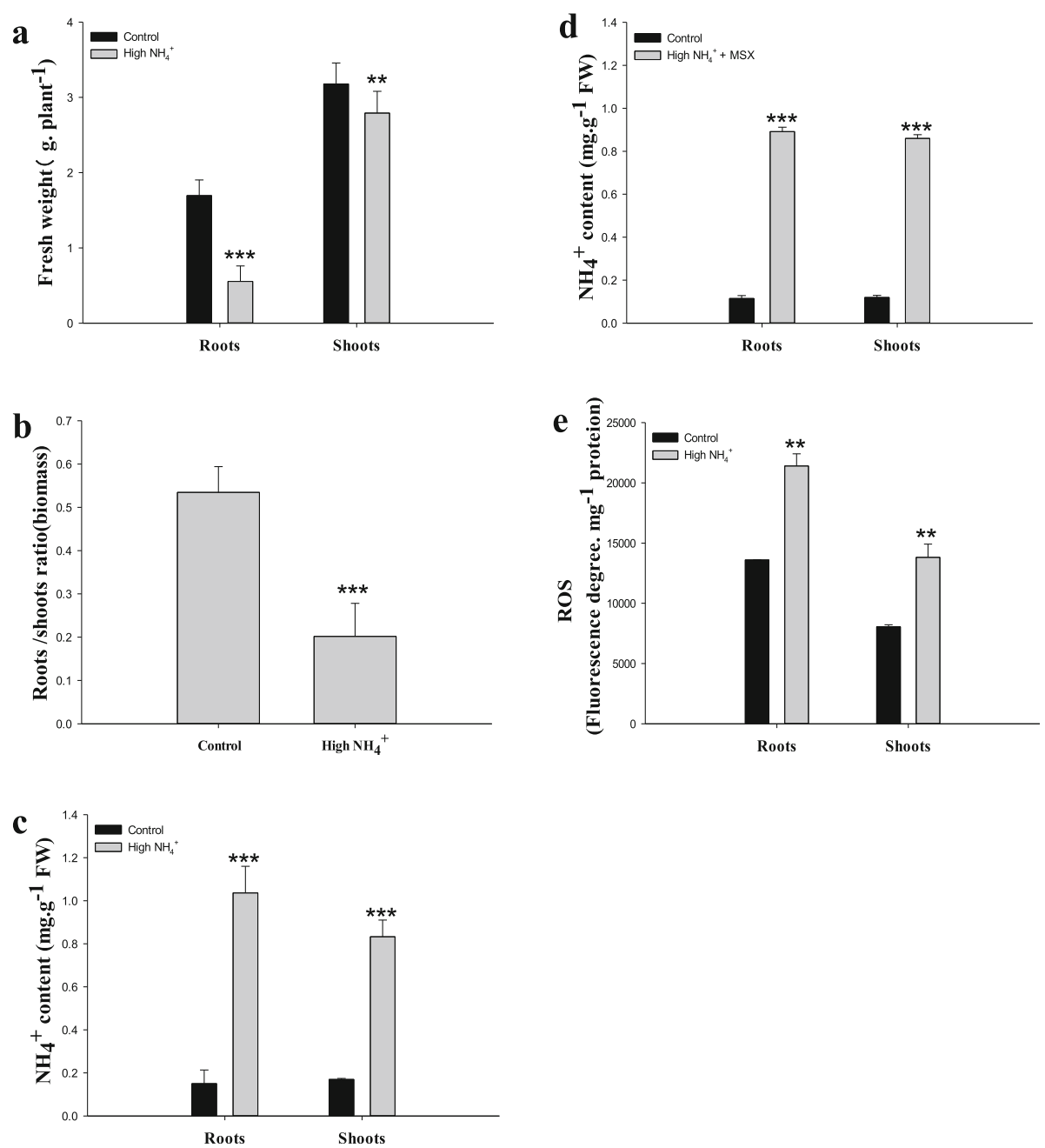

Fig. 1 Biological and physiological analyses of $\mathrm{NH}_{4}{ }^{+}$excess responses of rice. Rice seedlings aged $7 \mathrm{~d}$ were subjected to $\mathrm{NH}_{4}{ }^{+}$treatments for 14 $\mathrm{d}(\mathbf{a}-\mathbf{c}, \mathbf{e})$. a Fresh biomasses of roots and shoots. $\mathbf{b}$ Root-shoot ratios. c Free $\mathrm{NH}_{4}{ }^{+}$content and $\mathbf{e}$ Total ROS content in response to $\mathrm{NH}_{4}{ }^{+}$ treatments. $\mathbf{d}$ Acute $\mathrm{NH}_{4}{ }^{+}$excess simulation by treating with high $\mathrm{NH}_{4}{ }^{+}$for $4 \mathrm{~h}$ in the presence of $1 \mathrm{mM} \mathrm{MSX}$. Rice seedlings used for this experiment were $10 \mathrm{~d}$ old. Values indicated means \pm SE of three independent replicates. ${ }^{* *}$ and ${ }^{* * *}$ represented statistical significances at $p<0.01$ and 0.001 , respectively 
(growth modifications), a prompt status of internal $\mathrm{NH}_{4}{ }^{+}$excess is necessarily to be established without causing visible changes in plant growth (especially roots). Therefore, L-methionine-D,L-sulfoximine (MSX), a potent inhibitor of the primary $\mathrm{NH}_{4}{ }^{+}$assimilation pathway mediated by the activity of glutamine synthetases [35] was applied ( $1 \mathrm{mM})$ for $4 \mathrm{~h}$ in the presence of high $\mathrm{NH}_{4}{ }^{+}(20 \mathrm{mM})$. Considering the strong toxicity of MSX, proper conditions for the use of the drug were pre-tested to avoid lethal effects that lead to apoptotic lyses of cell components. In our hydroponics a $4 \mathrm{~h}$ incubation with $1 \mathrm{mM}$ MSX could efficiently result in an acute $\mathrm{NH}_{4}{ }^{+}$excess in both roots and shoots 5-6 fold that of the control conditions without any visible damage to rice seedlings (Fig. 1d). Thus the method allowed to simulate as fast as within $4 \mathrm{~h}$, 'saturable' $\mathrm{NH}_{4}{ }^{+}$excess circumstances inside both the roots and shoots to similar levels of the long term treatments (compare Fig. $1 \mathrm{c}$ \& d).

In line with the accumulation of free $\mathrm{NH}_{4}{ }^{+}$, bursts of reactive oxygen species (ROS) were observed (Fig. 1e), implying possible occurrence of ROS-induced reactions triggered by internal $\mathrm{NH}_{4}{ }^{+}$excess.

To further demonstrate the involvement of radical species in the early response to $\mathrm{NH}_{4}{ }^{+}$excess, we carried out respectively $\mathrm{DAB}\left(3,3^{\prime}\right.$-diaminobenzidine) and NBT (nitroblue tetrazolium) histochemical staining to trace the occurrence of $\mathrm{H}_{2} \mathrm{O}_{2}$ and $\mathrm{O}_{2}{ }^{-}$in newly-born roots and the 2nd leaves of the above treated rice plants. Results showed that upon the acute exposure to high $\mathrm{NH}_{4}{ }^{+}$, significant accumulation of $\mathrm{H}_{2} \mathrm{O}_{2}$ in both leaves and roots was detected with strong colored staining (Additional file 1, Fig. S1, a \& b). The stains were readily faded to close to the control levels following a feeding of $1 \%$ sucrose (Additional file 1 , Fig. S1, a \& b), indicating the fallback of the $\mathrm{H}_{2} \mathrm{O}_{2}$ burst to the normal levels. Consistent with the observation of $\mathrm{H}_{2} \mathrm{O}_{2}$, the NBT stained $\mathrm{O}_{2}{ }^{-}$showed closely similar changes (Additional file 2, Fig. S2, a \& b). This set of data rose questions that the burst of ROS (probably independent of their composition species) was an initiation step of the toxicity mediated by $\mathrm{NH}_{4}{ }^{+}$excess. Consequently, a set of ROS-triggered reactions or responses would be expected to take place as extensively described for abiotic stress responses. Indeed, according to the measurements of free amino acid contents (Additional file 3, Fig. S3), high $\mathrm{NH}_{4}{ }^{+}$also caused a significant accumulation of free amino acids in both roots and leaves, resembling a common protective response of that of a drought or salinity stress.

RNA-Seq analysis for preliminary identification of genes modulated by $\mathrm{NH}_{4}{ }^{+}$excess

According to above description, rice seedlings were treated with high $\mathrm{NH}_{4}{ }^{+}$in the presence of $1 \mathrm{mM}$ MSX for $4 \mathrm{~h}$ to establish an internal environment of $\mathrm{NH}_{4}{ }^{+}$excess. Then RNA-Seq analyses were carried out to seek for molecular responses related to this circumstance. Respectively 1077 and 1040 differentially expressed genes (DEGs) were obtained from roots and shoots, with $>2$ fold changes in their transcriptional levels (Additional file 4). Based on the GO classification, these genes mainly belonged to "metabolic process", "molecular function", "binding" and "biological process" (Additional file 5). Further KEGG pathway analysis revealed possible involvements of the responsive genes (DEGs) in stress response, photosynthetic adjustment, carbohydrate and amino acid metabolisms, preparation of hormone signaling pathways and re-adjustment of $\mathrm{NH}_{4}{ }^{+}$transport (Additional file 6). The significantly regulated genes were further summarized below within the framework of major processes they participate.

\section{Activation of GSH cycle for ROS scavenging}

Following the acute $\mathrm{NH}_{4}{ }^{+}$excess and the bursts of ROS (Fig. 1c, d, e), a most remarkable response was the strong induction of glutathione S-transferases (GST) genes (Fig. 2). Eleven GST genes were typically upregulated for $>7$ or even some tens to hundreds fold both in roots and shoots (Fig. 2ab, genes\#1-11). Among those GSTs, a OsGSTU4 (Os10g0528300, Fig. 2a, gene\#11) was the most severely induced by $>300$ and $>600$ fold in roots and shoots respectively, followed by 2 putative GST genes (Os10g0481300 and Os10g0527800) that were upregulated by $50-100$ fold in both parts. Whereas Os10g0525500 (77 fold) and Os03g0785900 (90 fold) showed strong induction in roots and shoots respectively (Fig. 2a, b). Since GSTs catalyze the transfer of superoxide free radicals to reductive glutathione (GSH) that leads to the detoxification of the oxidants, these changes in GST gene expression provide indications for the critical involvement of the GSH cycle in scavenging the $\mathrm{NH}_{4}{ }^{+}$excess induced ROS.

In line with strengthened demand of reducing power, a putative glutathione reductase gene (Os10g0415300) responsible for the recruitment of GSH was moderately upregulated ( $\sim 8$ fold) in roots and vigorously enhanced by 70 fold in shoots (Fig. 2a). Meanwhile, a NADH dehydrogenase gene (Os07g0564500) was stimulated by 127 folds in shoots, partly reflecting the coupling of energization and reducing power with the operation of the GSH cycle (Fig. 2a).

In addition to profound changes related to the GSH cycle, 7 peroxidase genes were suppressed in roots whereas a putative 1-Cys peroxiredoxin B gene (Os07g0638400) was significantly induced in both roots (19 fold) and shoots (179 fold) (Fig. 2a), corresponding to the contradictory roles of peroxidases in the cleavage / homeostasis maintenance of ROS [36]. 

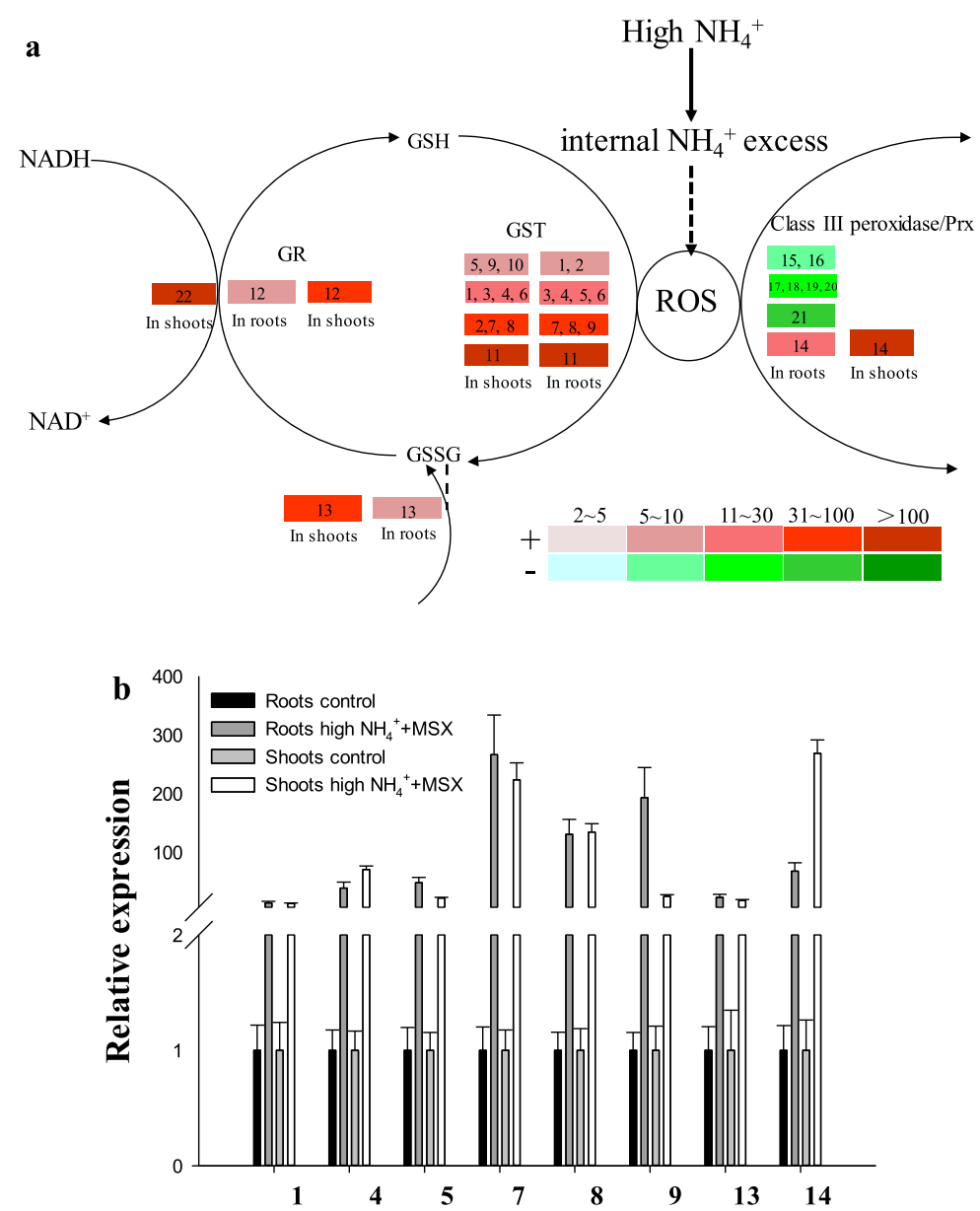

Fig. $\mathbf{2}$ Gene expression analyses of responsive ROS scavenging genes. a Differentially expressed genes obtained by RNA-Seq were illustrated in relation to the major pathways they were involved. Colored columns corresponded to fold changes of the transcripts as indicated by the definition of color gradients (bottom). The symbol ' + ' and the red gradient columns represented up-regulated genes and the fold of induction; while '-'and the green gradient columns referred to down-regulated genes. $\mathbf{b}$ The qRT-PCR validation of randomly selected genes coding for ROS scavenging systems. The relative expression levels were normalized against OsActin. Values indicated were means of three independent replicates. Numbered responsive genes were annotated as followings: 1. Os01 g0949700, putative glutathione S-transferase; 2. Os03g0785900, probable glutathione S-transferase GSTU1; 3. Os01g0369700, putative glutathione transferase 4; 4. Os01g0949800, putative glutathione S-transferase; 5. Os01g0949750, putative glutathione S-transferase; 6. Os10g0365200, glutathione S-transferase; 7. Os10g0527800, glutathione S-transferase OsGSTU12; 8. Os10g0481300, glutathione S-transferase; 9. Os10g0525500, glutathione S-transferase parC; 10. Os01g0372400, putative glutathione S-transferase; 11. Os10g0528300, glutathione S-transferase OsGSTU4; 12. Os10g0415300, glutathione reductase; 13. Os08g0557600, monodehydroascorbate reductase; 14. Os07g0638400, 1-Cys peroxiredoxin B; 15. Os05g0499300, peroxidase 1; 16. Os07g0677300, peroxidase 2; 17. Os05g0134800, Class III peroxidase 67; 18. Os02g0236600, Class III peroxidase 27; 19. Os03g0234900, Class III peroxidase 39; 20. Os03g0368000, Class III peroxidase 42; 21. Os06g0695300, Class III peroxidase 92; 22. Os07g0564500, NADH dehydrogenase [EC:1.6.99.3]

\section{Suppression of photosynthesis components and} contrasting regulation of energy producing carbohydrate metabolism

The chlorophyll a/b binding proteins of light-harvesting complexes (LHCs), also known as antenna proteins, are involved in gathering light energy (photons) of the primary reaction of photosynthesis [37]. Then trapped photons and electrons are transported to reaction center for further photochemical reactions. Disruption of these processes by photodamage, herbicides, or accumulation of highly active radicals will obviously hinder the progress of photosynthesis. Upon a prompt (4h) $\mathrm{NH}_{4}^{+}$ excess treatment, 6 genes coding for the LHC antenna proteins (4 LHC II and 2 LHC I, respectively), a PS I and a PS II reaction center genes were almost evenly suppressed by approximately 5 fold (Fig. 3), indicating the onset of the reduction of efficiencies of photon gathering and transfer. It would be easily supposed that apparent suppression of photosynthesis would accumulate along the progress of $\mathrm{NH}_{4}{ }^{+}$excess stress and growth inhibition would consequently occur. Meanwhile, Os12G0292400 coding for the small chain of Rubisco, the key enzyme catalyzes the fixation / assimilation of $\mathrm{CO}_{2}$, was downregulated by $\sim 5$ fold (Fig. 3), providing 


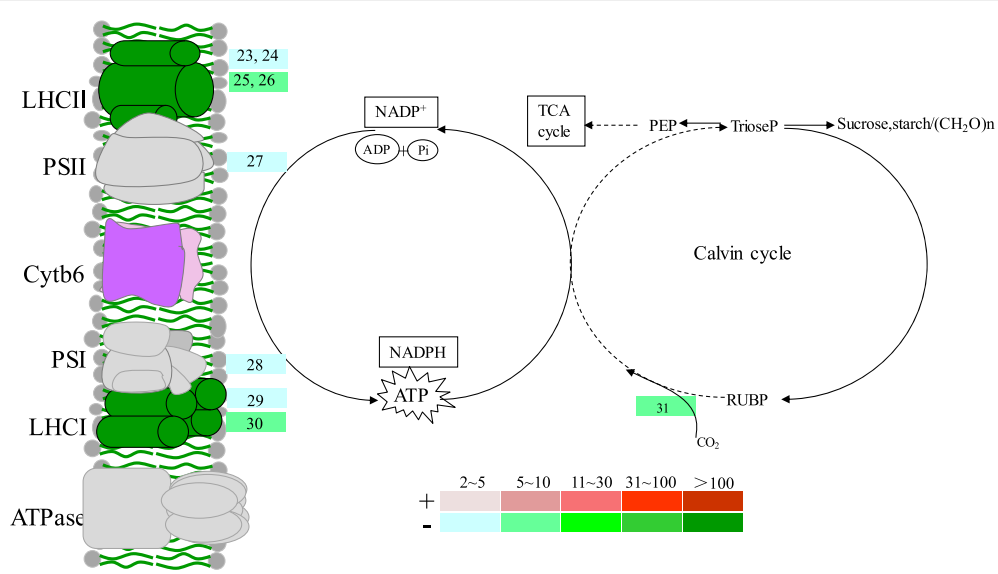

Fig. 3 Responsive genes involved in photosynthesis. Differentially expressed genes obtained by RNA-Seq were illustrated in relation to the major processes they were involved. Colored columns corresponded to fold changes of the transcripts as indicated by the definition of color gradients (bottom). The symbol ' + ' and the red gradient columns represented up-regulated genes and the fold of induction; while '-'and the green gradient columns referred to down-regulated genes. Numbered responsive genes were annotated as followings: 23. Os03g0592500, lightharvesting complex II chlorophyll a/b binding protein 2 (LHCB2); 24. Os07g0558400, light-harvesting complex II chlorophyll a/b binding protein 4(LHCB4); 25. Os01g0720500, light-harvesting complex II chlorophyll a/b binding protein 1 (LHCB1); 26. Os09g0346500, light-harvesting complex II chlorophyll a/b binding protein 1 (LHCB1); 27. Os03g0333400, photosystem II Psb27 protein (psb27); 28. (Os08g0560900), photosystem I subunit II (psaD); 29. Os06g0320500, light-harvesting complex I chlorophyll a/b binding protein 1 (LHCA1); 30. Os02g0197600, light-harvesting complex I chlorophyll a/b binding protein 3 (LHCA3); 31. Os12g0292400, ribulose-bisphosphate carboxylase small chain [EC:4.1.1.39] (rbcS)

further indication of compromised photosynthetic carbon production. Therefore, plant $\mathrm{NH}_{4}{ }^{+}$excess initiates and probably also develops the disruption of photosynthesis by interfering in the primary reaction and the Calvin Cycle.

Radical scavenging enzymes are activated and energized by the ATP producing processes including glycolysis and the TCA pathways. However, several genes involved in glycolysis and the TCA cycle were contrastingly regulated in roots and shoots (Fig. 4). In roots, genes coding for 2,3-bisphosphoglycerate-independent phosphoglycerate mutase (Os05g0482700, gene\#33) and fructose-bisphosphate aldolases (Os08g0120600, gene\#34 and Os01g0905800, gene\#35) of glycolysis, isocitrate dehydrogenase (Os05g0573200, gene\#36) and malate dehydrogenase (Os05g0574400, gene\#37) of the TCA cycle were down-regulated by $6-10$ fold following $4 \mathrm{~h}$ of $\mathrm{NH}_{4}{ }^{+}$excess treatments (Fig. 4a). Meanwhile genes involved in glycogen breakdown were suppressed in roots (Fig. 4a): phosphoenolpyruvate carboxykinase (Os10g0204400, gene\#32, - 19 fold), beta-glucosidase (Os09g0491100, gene\# 40,-11 fold), beta-glucosidase (Os02g0131400, foldgene\#41,-15 fold), beta-Dxylosidase 4 (Os04g0640700, gene\#42, -7fold), sucrose synthase (Os03g0401300, gene\#43, -8fold), betafructofuranosidase (Os02g0106100, gene $\# 44,-11$ fold). To the contrary, enhanced glycolysis/glycogen breakdown in shoots could be indicated by the upregulation of related genes (Fig. 4b): glucose-6-phosphate 1-dehydrogenase (Os02g0600400, gene\#39, + 5 fold), inorganic pyrophosphatase (Os05g0438500, gene\#49, + 18 fold), phosphoenolpyruvate carboxykinase (Os10g0204400, gene\#32, + 34 fold), beta-glucosidase (Os05g0366600, gene\#47, + 12 fold), beta-glucosidase (Os09g0511600, gene $48,+20$ fold). Notably, a pyruvate decarboxylase gene (Os05g0469600, gene \#38) of glycolysis, was specifically induced in shoots (Fig. 4b). In addition, two genes Os06g0222100 and Os08g0445700 coding for trehalose 6-phosphate synthase/phosphatases were induced by respectively 15 and 13 fold in roots (Fig. 4a, genes \#45,46), suggesting enhanced biosynthesis of the 'survival substance' [32] trehalose induced by $\mathrm{NH}_{4}{ }^{+}$excess stress.

\section{Sucrose feeding alleviates $\mathrm{NH}_{4}{ }^{+}$excess stress responses}

The above analyses revealed rather frustrating responses to $\mathrm{NH}_{4}{ }^{+}$excess stress in rice plant that closely associated with the consumption of carbohydrates for energy demand. Hence a sugar scarcity could accumulatively (to a longer time course) result in growth inhibition. To test this hypothesis, we fed $1 \%$ of sucrose as a sugar compensation to the high $\mathrm{NH}_{4}{ }^{+}(20 \mathrm{mM})$ hydroponics for $24 \mathrm{~h}$. This treatment compensated the sucrose consumption at high $\mathrm{NH}_{4}{ }^{+}$and allowed the sucrose contents in roots and shoots to restore to equivalent levels of the control $\left(1 \mathrm{mM} \mathrm{NH}_{4}{ }^{+}\right)$conditions (Fig. 5a). The sucrose feeding treatments further increased the free $\mathrm{NH}_{4}{ }^{+}$contents in roots, but significantly reduced $\mathrm{NH}_{4}{ }^{+}$accumulation to the shoots (Fig. 5b).

Under high $\mathrm{NH}_{4}{ }^{+}$conditions, the expression levels of 3 AMT1 genes (OsAMT1;1-Os04g0509600, OsAMT1;2Os02G0620500 and OsAMT1;3-Os02G0620600) were 


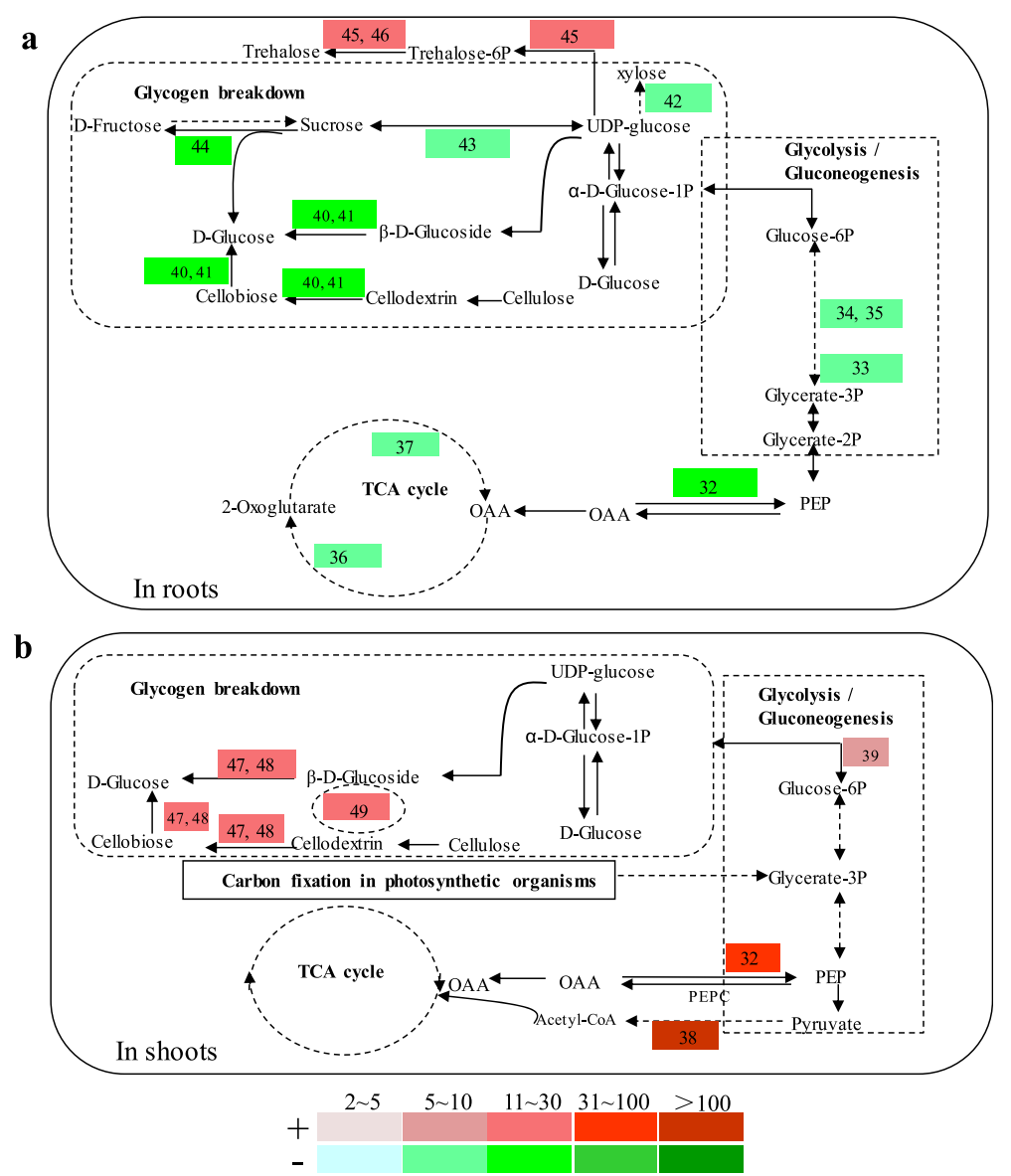

Fig. 4 Responsive genes involved in carbohydrate metabolisms in roots (a) and shoots (b). Differentially expressed genes obtained by RNA-Seq were illustrated in relation to the major processes they were involved. Colored columns corresponded to fold changes of the transcripts as indicated by the definition of color gradients (bottom). The symbol ' $t$ ' and the red gradient columns represented up-regulated genes and the fold of induction; while'-' and the green gradient columns referred to down-regulated genes. Numbered responsive genes were annotated as followings: 32. Os10g0204400, phosphoenolpyruvate carboxykinase (ATP) [EC:4.1.1.49] (pckA); 33. Os05g0482700, 2,3-bisphosphoglycerateindependent phosphoglycerate mutase [EC:5.4.2.12] (gpml); 34. Os08g0120600, fructose-bisphosphate aldolase, class I [EC:4.1.2.13] (ALDO); 35. Os01g0905800, fructose-bisphosphate aldolase, class I [EC:4.1.2.13] (ALDO); 36. Os05g0573200, isocitrate dehydrogenase [EC:1.1.1.42] (IDH); 37. Os05g0574400, malate dehydrogenase [EC:1.1.1.37] (MDH2); 38. Os05g0469600, pyruvate decarboxylase [EC:4.1.1.1]; 39. Os02g0600400, glucose-6phosphate 1-dehydrogenase [EC:1.1.1.49] (G6PD); 40. Os09g0491100, beta-glucosidase [EC:3.2.1.21]; 41. Os02g0131400, beta-glucosidase [EC:3.2.1.21]; 42. Os04g0640700, beta-D-xylosidase 4 [EC:3.2.1.37] (XYL4); 43. Os03g0401300, sucrose synthase [EC:2.4.1.13]; 44. Os02g0106100, betafructofuranosidase [EC:3.2.1.26] (sacA); 45. Os08g0445700, trehalose 6-phosphate synthase / phosphatase [EC:2.4.1.15 3.1.3.12] (TPS); 46. Os06g0222100, trehalose 6-phosphate phosphatase [EC:3.1.3.12] (otsB); 47. Os05g0366600, beta-glucosidase [EC:3.2.1.21]; 48. Os09g0511600, betaglucosidase [EC:3.2.1.21], 49. Os05g0438500, inorganic pyrophosphatase [EC:3.6.1.1]

suppressed respectively by 3, 67 and 6 fold in roots, implying a reduction in $\mathrm{NH}_{4}^{+}$uptake activity. With the supplement of sucrose (1\%) to the high $\mathrm{NH}_{4}^{+}$hydroponics (Fig. 5c), their expression levels restored to close to the 'normal' levels (at $1 \mathrm{mM} \mathrm{NH}_{4}^{+}$). This implied a release of ammonium transporting activity from suppression by $\mathrm{NH}_{4}{ }^{+}$excess, thus contributed to enhanced $\mathrm{NH}_{4}{ }^{+}$accumulation in roots under high $\mathrm{NH}_{4}{ }^{+}$plus sucrose condition. Whereas the reduced free $\mathrm{NH}_{4}{ }^{+}$content under the same condition in shoots indicated probably the efficient utilization of $\mathrm{NH}_{4}{ }^{+}$upon the addition of sucrose (Fig. 5b). Meanwhile the GS (Fig. 5d) and GOGAT (Fig. 5e) activities were respectively enhanced by $17 \%$ (GS) and
$29 \%$ (GOGAT) in roots following the sucrose feeding treatments, indicating a restoration of $\mathrm{NH}_{4}{ }^{+}$assimilation activities from initial suppression by $\mathrm{NH}_{4}{ }^{+}$excess.

Upon the compensation of sucrose source, the total ROS contents in both roots and shoots were lowered down by $20-30 \%$, close to the levels determined at control $\left(1 \mathrm{mM} \mathrm{NH}_{4}{ }^{+}\right)$conditions (Fig. 6a). Accordingly, the GSH content and GST activity were significantly reduced to the initial levels (at $1 \mathrm{mM} \mathrm{NH}_{4}^{+}$), no longer showing strong induction by $\mathrm{NH}_{4}{ }^{+}$excess (Fig. 6b, c). Unexpectedly, no significant changes were observed with the activities of classical defense enzymes CAT, POD and SOD under either treatment (Fig. 6d, e, f). Together 

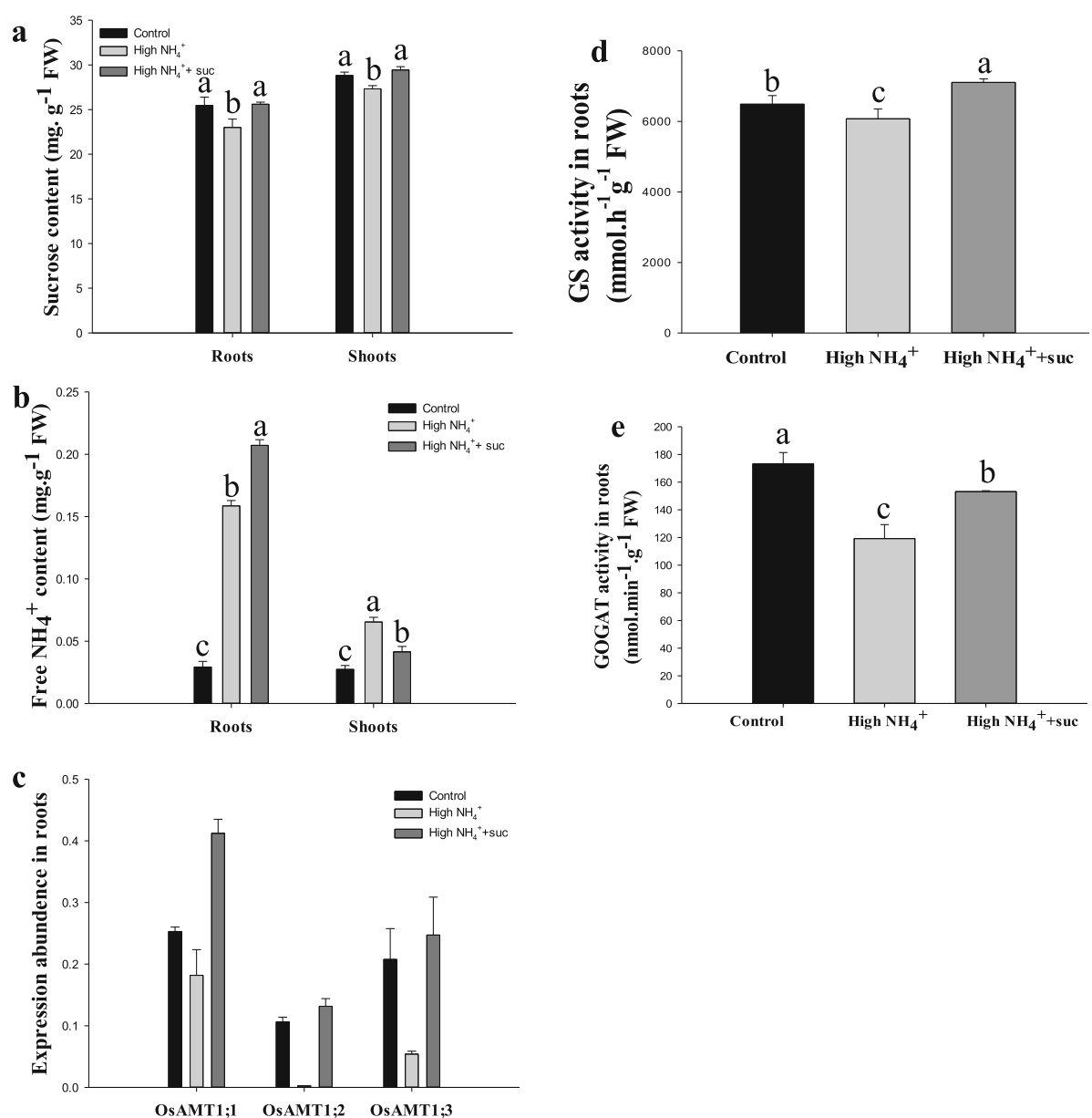

Fig. 5 Effects of sucrose feeding on $\mathrm{NH}_{4}{ }^{+}$accumulation, uptake and assimilation processes. Seedlings aged $10 \mathrm{~d}$ were subjected to control (1 mM $\left.\mathrm{NH}_{4}{ }^{+}\right)$, high $\mathrm{NH}_{4}{ }^{+}(20 \mathrm{mM})$ or high $\mathrm{NH}_{4}{ }^{+}+$suc $\left(20 \mathrm{mM} \mathrm{NH}_{4}{ }^{+}+1 \%\right.$ sucrose) treatments for $24 \mathrm{~h}$. a Sucrose content, $\mathbf{b}$ free $\mathrm{NH}_{4}{ }^{+}$content, $\mathbf{c}$ the expression profiles of OsAMT1;1, OsAMT1;2 and OsAMT1;3 determined by qRT-PCR, $\mathbf{d}$ GS enzyme activity, e GOGAT enzyme activity. Data were means \pm SE of three independent replicates. Letters on the bars represented statistical significances

with the gene expression analyses (Fig. 2), our results demonstrated that the activation of GSH reducing pathway is probably a featured response of rice in dealing with $\mathrm{NH}_{4}^{+}$excess and ROS accumulation. Finally, in consistent with the decreased level of ROS, Rubisco activity was elevated by $24 \%$ (compared with high $\mathrm{NH}_{4}^{+}$) in shoots with the presence of sucrose feeding (Fig. $6 \mathrm{~g}$ ), suggesting enhanced efficiency of primary $\mathrm{CO}_{2}$ fixation activity.

Taken together, this set of experiments indicated that sucrose feeding could effectively alleviate rice plant from carbon scarcities exerted by internal $\mathrm{NH}_{4}{ }^{+}$excess and ROS stresses.

\section{Discussion}

The performance of internal $\mathrm{NH}_{4}{ }^{+}$excess is an issue of physiological and practical significance

Due to particular water-flooding and anaerobic environment, $\mathrm{NH}_{4}{ }^{+}$retains as the major form of $\mathrm{N}$ nutrient available to paddy rice. For the present high-yielding rice production in China, to satisfy the strengthened $\mathrm{N}$ demand for high levels of grain yields, nitrogen fertilizers are applied as high as typically $300 \mathrm{~kg} \mathrm{ha}^{-1} \mathrm{~N}$. The total amount of nitrogen normally composes of $\sim 40 \%$ of basal $\mathrm{N}$ at the seedling stage and respectively $30 \%$ of topdressed $\mathrm{N}$ at the tillering and grain-filling stages to ensure sufficiently higher $\mathrm{N}$ contents in the roots and photosynthetic leaves. This amount of nitrogen is thought to be overused since the grain yield is saturated; but is necessary for farms' goal of a high grain yield [10$12,38,39]$. As the consequence of $\mathrm{N}$ overuse, a persistent internal $\mathrm{NH}_{4}{ }^{+}$excess circumstance exists for rice plant to cope with. Therefore, a study focuses on such farming-intervened special circumstances would be helpful in discovering 'bottlenecked' constraints and adaptation strategies related to the (molecular) physiological and agronomic respects of $\mathrm{N}$ performances in rice. Then questions rise for researchers: what the excessive portion 

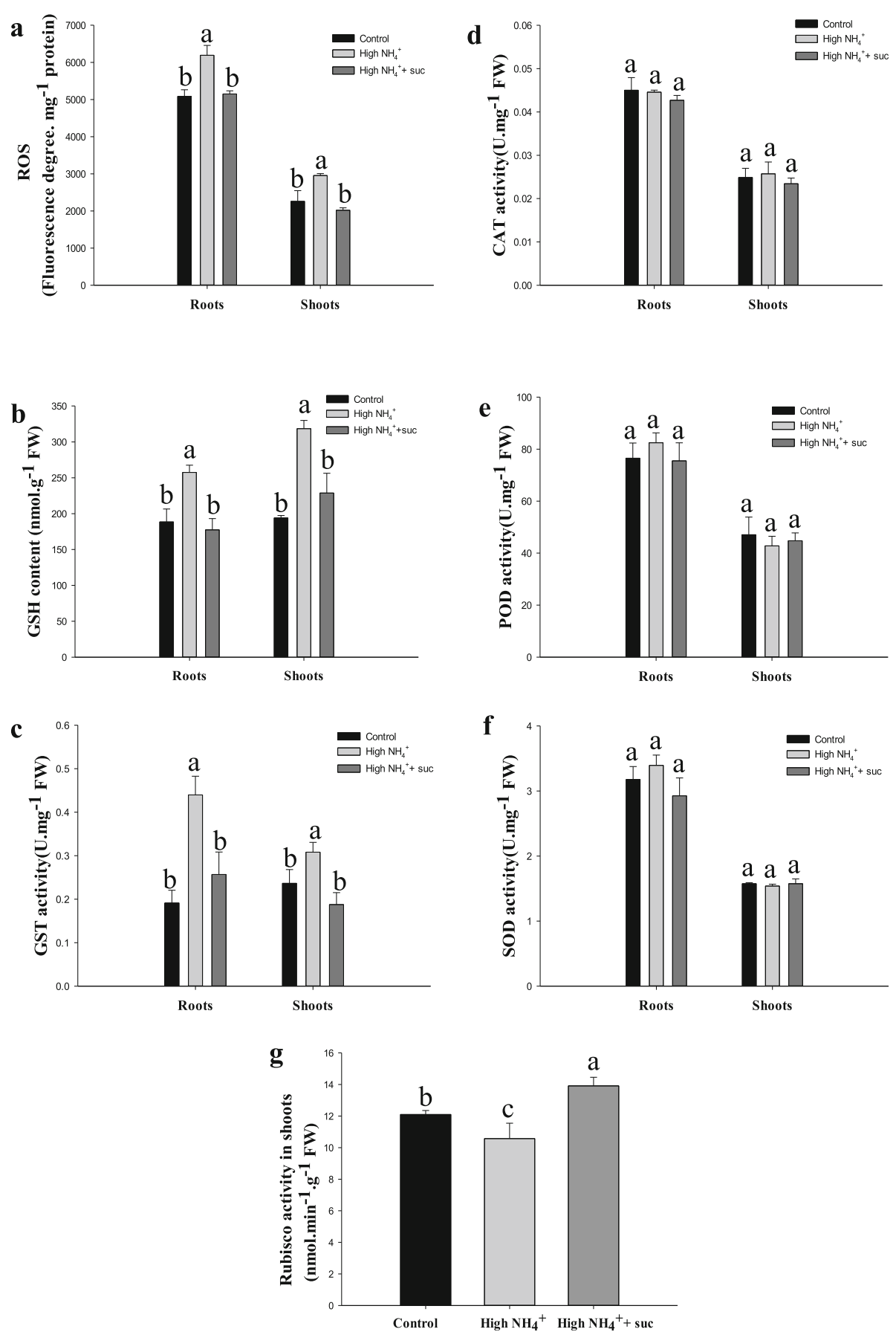

Fig. 6 Effects of sucrose feeding on ROS accumulation, ROS scavenging enzymes and Rubisco activities. Seedlings aged $14 \mathrm{~d}$ were subjected to control $\left(1 \mathrm{mM} \mathrm{NH}_{4}{ }^{+}\right)$, high $\mathrm{NH}_{4}{ }^{+}(20 \mathrm{mM})$ or high $\mathrm{NH}_{4}{ }^{+}+$suc $\left(20 \mathrm{mM} \mathrm{NH}_{4}{ }^{+}+1 \%\right.$ sucrose $)$ treatments for $24 \mathrm{~h}$. a Total ROS accumulation represented by fluorescence degrees, b GSH content, $\mathbf{c}-\mathbf{g}$ Enzymes activity assays for c GST, d CAT, e POD, f SOD and $\mathbf{g}$ Rubisco. Experimental conditions were the same as described in Fig. 5. Data were expressed as means \pm SE of three independent replicates. Letters on the bars represented statistical significances

of $\mathrm{N}$ does in rice plant? What is the main constraint that limits the excess $\mathrm{N}$ from conversion to further productivity?

Under the field conditions of $\mathrm{N}$ overuse (say 300 $\mathrm{kg} \mathrm{ha}^{-1} \mathrm{~N}$ ), suppose the $\mathrm{N}$ fertilizer exists totally in the form of $\mathrm{NH}_{4}{ }^{+}$ions and are mainly distributed within a depth of $30 \mathrm{~cm}$ (including water body), the 4:3:3 proportions of total $\mathrm{N}\left(\mathrm{NH}_{4}^{+}\right)$will roughly result in $2.2,1.7$ and $1.7 \mathrm{mM}$ of $\mathrm{NH}_{4}^{+}$concentrations, such concentrations will be further compromised due to the buffering 
capacity of the soil $\left(\mathrm{NH}_{4}{ }^{+}\right.$adhered to soil particles), finally the free $\mathrm{NH}_{4}{ }^{+}$ions around the roots could be in a "safe" range that does not stress the roots. As the result, $\mathrm{N}$ overuse in rice field is not exactly an external high $\mathrm{NH}_{4}{ }^{+}$stress, for $\mathrm{N}$ fertilizer topdressing is normally applied almost evenly to the surface of water flooded field, not by localized dressing that brings high $\mathrm{NH}_{4}{ }^{+}$to the roots. In this circumstance, the problem of $\mathrm{N}$ overuse can be simplified as an $\mathrm{NH}_{4}{ }^{+}$excess inside the plant.

It is to this respect we design the experiments. Although like many others, for better controlling of experimental conditions we use hydroponics to address the question. Particular attentions have been paid to avoid growth divergence during the whole set of experiments. To isolate the specific reactions initiated by internal $\mathrm{NH}_{4}{ }^{+}$excess, we establish an acute method that creates sufficient levels of $\mathrm{NH}_{4}{ }^{+}$excess in $4 \mathrm{~h}$ by the presence of MSX to block (targeted to GS) the assimilation of $\mathrm{NH}_{4}{ }^{+}$ acquired into the plant. For the use of MSX, we clearly notice its strong toxicity to plants and serious precautions are made to find a "safe" condition by pre-testing its effects on induction of significant $\mathrm{NH}_{4}{ }^{+}$accumulation in shoots and its toxic influences to the seedlings. When MSX was supplied at $0.1 \mathrm{mM}$ concentration, $\mathrm{NH}_{4}{ }^{+}$accumulation in shoots within $4 \mathrm{~h}$ is much less profound (12 fold) than at $1 \mathrm{mM}$ (5-6 fold). Within the first $4 \mathrm{~h}$ of incubation with $1 \mathrm{mM}$ of MSX, rice seedlings remain clearly unaffected, indicating no injury occurred at this time period; with extended incubation to $12 \mathrm{~h}$, leaves turn yellowish and somehow curl, and finally up to $24 \mathrm{~h}$, seedlings start dying. In addition, our previous work on optional gene expression observation [29], we finally use $4 \mathrm{~h}$ treatments with high $\mathrm{NH}_{4}{ }^{+}$and the presence of 1 mM MSX.

\section{The toxicity of internal $\mathrm{NH}_{4}{ }^{+}$excess initiates with bursts of ROS}

High $\mathrm{NH}_{4}{ }^{+}$stress and toxicity have been considered as a major human-intervened environmental distress exerted on plants and attracted extensive research interests. Researches on these topics have focused on the identification of mechanisms or pathways that primarily modulate the biological modifications of root architectures [2024]. Solid evidences have shown the re-configuration of plant root morphology in response to $\mathrm{NH}_{4}{ }^{+}$stresses is tightly controlled through the interactions with plant hormone signaling pathways $[13,14,24,25,27]$. Whereas $\mathrm{NH}_{4}{ }^{+}$toxicities could be attributed to ion imbalances [20], intracellular $\mathrm{pH}$ disturbance [40], energy consumption due to invalid $\mathrm{NH}_{4}{ }^{+}$cycles in roots [13, 41]. Assessments of $\mathrm{NH}_{4}{ }^{+}$stress responses in plant roots and its biological toxicities, to a great extent, relies on the establishment of measurable growth phenotypes that requires effects or reactions to accumulate for a desired time course. These analyses are obviously important in addressing the mode-of-action of physiological effects or processes developed along the progresses of the treatments. To the other hand, since plants keep growing and developing during the experimental periods, these accumulative observations might be not satisfactory for capturing the initial reactions or the nature of $\mathrm{NH}_{4}{ }^{+}$excess stresses. Therefore, it seems inevitably necessary to isolate the initial reactions triggered by internal $\mathrm{NH}_{4}{ }^{+}$ excess from rather mixed accumulative effects.

Our results with physiological measurements and histochemical observations clearly demonstrate that the burst of ROS radicals is a foremost straightforward consequence readily along the acute internal $\mathrm{NH}_{4}{ }^{+}$excess (Fig. 1c- e; Additional files 1, 2). Then we obtain a whole set of indications supporting that the essential nature of the toxicity of $\mathrm{NH}_{4}{ }^{+}$excess in rice plant is probably initiated by the induction of ROS bursts and the downstream reactions: 1) since photosynthetic components are sensitive to radical injuries, we observe reduced abundances of genes involved in photon-caption and compromised primary $\mathrm{CO}_{2}$ fixation activity of the $\mathrm{Ru}$ bisco enzymes (Figs. 3 and 6g); 2) downstream the ROS burst, we identify that GSH cycling acts as a seemingly specific defense mechanism for scavenging ROS, using both transcription and enzyme activity changes of GST genes as indicators (Figs. 2 and 6); 3) to energize the highly energy-consuming ROS cleavage reactions, we observe gene expression indications for a reduced complex sugar synthesis and strongly enhanced breakdown of active simple sugars in shoots (Fig. 4), such shift in carbon metabolism points to a strengthened production of carbon skeletons. Conversely, the enhancements of energy and carbon skeleton production seem not accordingly take place in roots (Fig. 4), implying a sacrifice of root growth for stress escaping.

To this end, the nature of the toxicity of $\mathrm{NH}_{4}{ }^{+}$excess in rice plant resembles largely that has been well defined for an abiotic stress, such as drought or salinity stresses described in other plant species [32, 34], and shares same origins-oxidative injuries and ROS induced energy and carbon skeleton consumption. There are sufficient speculations of the induction of ROS under high $\mathrm{NH}_{4}{ }^{+}$stresses. In tobacco and grapevine suspension cells, a 24-treatment with high $\mathrm{NH}_{4}{ }^{+}$or $\mathrm{NaCl}$ results in the generation of ROS that signals the redirection of amino acid synthesis and metabolisms [42] (Skopelitis et al., 2006 PC). In the hydroponics of Myriophyllum mattogrossense, the induction of oxidative stress responses by an excess of ammonia $\left(\mathrm{NH}_{3}\right.$ and $\left.\mathrm{NH}_{4}{ }^{+}\right)$is deduced from the increased activities of antioxidative protection enzymes [43] (Nimptsch et al., 2007, Chemosphere). After a $26 \mathrm{~h}$ of $\mathrm{N}$ depletion, resupplement of even $1 \mathrm{mM}$ of $\mathrm{NH}_{4}{ }^{+}$to Arabidosis is suspected to induce 
oxidative stress responses as deduced from elevated activities of antioxidant scavengers [44] (Patterson 2010 PEC). Under $25 \mathrm{mM} \mathrm{NH}_{4}{ }^{+}$, elevated $\mathrm{H} 2 \mathrm{O} 2$ can be detected in Arabidosis and participates the modulation of AMOS1/EGY1-dependent ABA signaling 28]. In rice, continuous exposure for 6 days to extremely high concentration of $\mathrm{NH}_{4}{ }^{+}(80 \mathrm{mM})$ results in significant accumulation of ROS and activates the involvement of heme oxygenase 1 in the alleviation of $\mathrm{NH}_{4}{ }^{+}$toxicity [18] (Xie et al., 2015 PCE). In general, for most of phenotyperelated assessments, plants are subjected to continuous $\mathrm{NH}_{4}{ }^{+}$stresses so that solid phenotypes develop, and in these cases, elevated of ROS levels are considered as fundamental signals or triggers for the activation of specific molecular pathways. For the identification of "early" responses before the formation of a growth phenotype, transcriptomic studies focus on the gene expression regulation to form speculations on the involvement of ROS and downstream reactions in plants' responses to high $\mathrm{NH}_{4}{ }^{+}$stresses $[19,29]$. However, the induction of ROS remains to be clearly quantified in relation to the accumulation of free $\mathrm{NH}_{4}{ }^{+}$inside the plant and the internal effects of $\mathrm{NH}_{4}{ }^{+}$excess also need to be isolated from stress responses impended exogenously to the roots. Here in this report, we present with physiological and histochemical observations, the acute induction of ROS readily accompanied with the formation of internal $\mathrm{NH}_{4}{ }^{+}$excess, providing a solid evidence that the frustrating performance of internal $\mathrm{NH}_{4}{ }^{+}$excess integrates and probably also originated from the burst of ROS.

Carbon scarcity is a major constraint on the effectiveness of the internal $\mathrm{NH}_{4}^{+}$excess

Our whole set of data supports a prediction that a carbon scarcity occurs along with the internal $\mathrm{NH}_{4}{ }^{+}$excess, including the headstream reduction of photosynthetic carbon assimilation (Fig. 3) and the redirection of carbohydrate metabolisms to enhanced energy and $\mathrm{C}$ skeleton production (Fig. 4). The prediction is further proofed by the sucrose feeding experiments that eventually cancel the negative effects associated with $\mathrm{NH}_{4}{ }^{+}$excess (Fig. 5 and 6). Sucrose is chosen for the complementation of carbon scarcity because this sugar is the major form of active carbon source in the phloem and can be transported and allocated in plant tissues and organs [45].

However, the issue of "carbon scarcity" is rather a common view as the consequence of a stress response, since numerous reports have raised such speculation $[20-24,29,32,46]$. In this report, we present data sets that point to the initiation and development of carbon scarcity (Figs. 2, 3 and 4). Therefore, the occurrence of carbon scarcity and its relationship to $\mathrm{NH}_{4}{ }^{+}$excess and / or $\mathrm{N}$ overuse are no longer a hypothesis but a conclusive notion with solid data supports. To this respect, the nature of $\mathrm{NH}_{4}{ }^{+}$toxicity can be explained as the development and accumulation of carbon scarcity that eventually lead to growth inhibition or death of the plants.

As demonstrated by sucrose feeding experiment of the present work (Figs. 5 and 6) and reports from Arabidopsis under high $\mathrm{NH}_{4}{ }^{+}$[46], salinity stresses [47] (Qiu et al., Biologia Plantarum) or chickpea under salinity stresses [48] (Khan et al., 2016 JXB), enhancement of active sugar income would be an efficient approach of overcoming the shortage of carbon source. Whereas in the field, supplement of elevated concentration of $\mathrm{CO}_{2}$ is a straightforward regulation to enhance photosynthetic carbon production and the grain yields of cereals [4952] (Ainsworth 2005; Leakey 2009; Becker 2016; Kimball 2016 Current opinion). However, reports have shown that continuous exposure to high $\mathrm{CO}_{2}$ for longer than 3-5 growth seasons leads to a phenomenon of acclimation due to a significant reduction of stomatal conductance and limits of nitrogen nutrient $[49,53]$ (Seneweera et al., 2002 Funct. Plant biology; Ainsworth 2005). Such acclimation to elevated $\mathrm{CO}_{2}$ can be partly hindered by supplement of sufficient nitrogen [54] (Stitt, 1999), providing an implication that this approach may be more effective under current $\mathrm{N}$ overuse in rice. Additionally, reports has shown that the addition of $\mathrm{CaCO}_{3}$ to the roots alleviates the growth inhibition of cucumber from high $\mathrm{NH}_{4}{ }^{+}$stress [55] (Roosta, 2008). This manner of carbon feeding is expected to be practically useful for China's rice farming because a great plot of rice production locates to the low $\mathrm{pH}$ red soils, and lime is often applied as a soil conditioner for the purpose of $\mathrm{pH}$ neutralization.

Efficient $\mathrm{NH}_{4}{ }^{+}$uptake through AMT transporters is closely related to the removal of the substrate by GSmediated assimilation processes, ineffective removal or accumulation of $\mathrm{NH}_{4}{ }^{+}$would hinder the uptake of the ions-a phenomenon of so-called feedback inhibition [[46, 56-58]. The strong suppression of root-specific AMT genes, OsAMT1;2 and OsAMT1;3 under rapid $\mathrm{NH}_{4}{ }^{+}$excess conditions (Fig. 5c) and reduction of GS and GOGAT activities (Fig. 5d, e) provide further evidence of such feedback regulation in rice. Here, upon the carbon compensation by sucrose feeding, the $\mathrm{NH}_{4}{ }^{+}$ assimilation activities restore to normal rates (normal $\mathrm{NH}_{4}{ }^{+}, 1 \mathrm{mM}$ ) and the AMT expression levels are accordingly enhanced (Fig. 5c, d, e), supportedly suggesting that carbon scarcity may be a major cause that leads to feedback inhibition of $\mathrm{NH}_{4}{ }^{+}$uptake.

\section{Conclusions}

To summarize, the present work reveals that the essential nature of internal $\mathrm{NH}_{4}{ }^{+}$excess stresses in rice plant is closely correlated to its accompanying ROS bursts. Elevated oxidative radicals impair the photosynthetic 
components and lead to reduced primary carbon production. The activation of ROS scavenging processes redirects the carbohydrate metabolisms for enhanced energy and carbon skeleton production and strengthens carbon scarcity in rice plant. A sucrose feeding effectively alleviates frustrating stress responses. Therefore we conclude that carbon scarcity is probably a major constraint on the effectiveness of internal $\mathrm{NH}_{4}{ }^{+}$excess under current $\mathrm{N}$ fertilizer overuse of high-yielding rice.

\section{Methods}

\section{Plant growth and treatments}

Rice seeds of Oryza. sativa ssp. Japonica Nipponbare were obtained from Prof. Yingguo Zhu's group, College of Life Sciences, Wuhan University. The seeds were surface sterilized, germinated and seedlings were grown in a growth chamber according to previously described [29]. The growth chamber was set with 16/8 h day/night, 27/ $25^{\circ} \mathrm{C}$,day/night; The light intensity was $400 \mu \mathrm{mol} \mathrm{m}^{-2}$ $\mathrm{s}^{-1}$, relative humidity was set at $70 \%$. Seedlings were grown in the IRRI solution [29] until desired ages. The $\mathrm{pH}$ of hydroponics was buffered to 5.7 with $10 \mathrm{mM}$ MES and renewed every $48 \mathrm{~h}$. For treatments seedlings of uniform sizes were transferred to cylinder polyvinyl chloride culturing tanks $(10 \mathrm{~cm}$ inner diameter and $15.5 \mathrm{~cm}$ height) filled with $1.0 \mathrm{~L}$ of nutrient solutions supplied with desired concentrations of $\mathrm{NH}_{4}{ }^{+}$. Eight seedlings separated into 4 holes were placed onto the lids of each culturing tanks. At the time of harvest, seedlings of each tank were pooled and served as one duplicate of every treatment. The treatments were duplicated in 3 individual culturing tanks. For long-term growth tests, uniform seedlings of $7 \mathrm{~d}$ were treated with either $1 \mathrm{mM}$ (control) or $20 \mathrm{mM}$ (high $\mathrm{NH}_{4}^{+}$) of $\mathrm{NH}_{4} \mathrm{Cl}$ supplemented to nitrogen-free IRRI solutions for further 14 days with daily refreshment of the culture solutions. To achieve a rapid $\mathrm{NH}_{4}{ }^{+}$excess in rice plants without causing a growth discrepancy, so that $\mathrm{NH}_{4}{ }^{+}$excess-responsive genes could be analyzed at the early stages of responses, 10-d old seedlings were promptly treated with 'control' or 'high $\mathrm{NH}_{4}{ }^{+}$, (see above) for $4 \mathrm{~h}$ in the presence of $1 \mathrm{mM}$ methionine sulfoximine (MSX, a potent inhibitor of glutamine synthetase) to block the major assimilation of $\mathrm{NH}_{4}{ }^{+}$. For sucrose feeding experiments, 14-d old seedlings were treated with control $\left(1 \mathrm{mM} \mathrm{NH}_{4}{ }^{+}\right)$or high $\mathrm{NH}_{4}{ }^{+}(20$ $\left.\mathrm{mM} \mathrm{NH}_{4}{ }^{+}\right)$in IRRI solution in the presence of $1 \%(\mathrm{w} / \mathrm{v})$ sucrose for $24 \mathrm{~h}$. To avoid the burst of microbes associated with sucrose-containing hydroponics, antibiotics penicillin $\left(50 \mathrm{mg} \mathrm{L}^{-1}\right)$ and chloramphenicol $\left(25 \mathrm{mg} \mathrm{L}^{-1}\right)$ were included to the culturing solution according to Lejay's description [59]. Same strength of antibiotics was included in the control seedlings (control $\mathrm{NH}_{4}{ }^{+}$and high $\mathrm{NH}_{4}{ }^{+}$treated plants). Also in order to prevent possibly undesired impacts, the treatment was limited to within $24 \mathrm{~h}$.

\section{RNA-Seq and quantitative real-time PCR analyses}

Total RNAs from treated root or shoot samples was extracted withTRIzol total RNA extraction kit (Invitrogen, Carlsbad, CA, USA) according to the manufacturer's protocol. For RNA-Seq analysis, RNAs from control (1 $\mathrm{mM} \mathrm{NH}_{4}{ }^{+}$)or high $\mathrm{NH}_{4}{ }^{+}$plus $1 \mathrm{mM} \mathrm{MSX}$ treated $(4 \mathrm{~h})$ tissue samples were used for library construction and sequencing. Data extraction, identification of differentially expressed genes (DEGs) and functional annotation were analyzed according to our previous work [29]. DEGs were designated with expression fold changes greater than $2(p<0.05)$ between the rapid $\mathrm{NH}_{4}{ }^{+}$accumulation (high $\mathrm{NH}_{4}{ }^{+}+\mathrm{MSX}$ ) and the control conditions.

Quantitative real-time PCR (qRT-PCR) analyses was carried out to reveal possible responses at the gene expression level related to special conditions such as $\mathrm{NH}_{4}{ }^{+}$ excess stress or sucrose feeding treatments. About $1 \mu \mathrm{g}$ of total RNA was used to synthesize first-strand cDNAs using the PrimeScript ${ }^{\mathrm{tw}}$ RT Master Mix (Perfect Real Time, TaKaRa, Japan) according to the manufacturer's description. Primer sequences used for qRT-PCR were listed in Additional file 7. Thermocycling and fluorescence detection were performed with C1000 Thermal Cycler CFX96 Real-Time System (Bio-Rad) using the SYBR Premix Ex Taq (TaKaRa, Japan) as indicated by the manufacturer's protocol. The reaction was performed under the following conditions: $95^{\circ} \mathrm{C}$ for $30 \mathrm{~s}$, followed by 44 cycles of $95^{\circ} \mathrm{C}$ for $10 \mathrm{~s}, 60^{\circ} \mathrm{C}$ for $15 \mathrm{~s}$ and $72{ }^{\circ} \mathrm{C}$ for $15 \mathrm{~s}$. For fold change analysis, gene expression abundance was quantized with $-2^{\Delta \Delta \mathrm{Ct}}$ and normalized against the internal OsActin gene. PCR amplifications were repeated three times using cDNA templates synthesized from three independent plant samples.

\section{Tissue free $\mathrm{NH}_{4}{ }^{+}$, free amino acids, GSH and sucrose contents assays}

Fresh root or shoot samples $(0.2 \mathrm{~g})$ were ground into fine powder in liquid $\mathrm{N}_{2}$ and homogenized in $5 \mathrm{ml}$ of 0.3 $\mathrm{mM}$ sulfuric acid. The supernatant was harvested by centrifugation with $20,000 \mathrm{~g}$ at $4{ }^{\circ} \mathrm{C}$ for $20 \mathrm{~min}$. For free $\mathrm{NH}_{4}{ }^{+}$measurements, aliquots of supernatant $(200 \mu \mathrm{L})$ were mixed with $4.9 \mathrm{~mL}$ each of phenol-sodium nitroprusside solution and alkaline hydrochlorite solution according to the method of Weatherbur [60]. The color reaction was allowed to develop at room temperature for 1hbefore the colorimetric absorbance been measured at $625 \mathrm{~nm}$. The content of free amino acids was determined by a $\mathrm{T}$-free AA assay kit (Nanjing Jiancheng Bioengineering Institute, Nanjing, China) using glycine as the standard [61]. The tissue GSH content was measured according to Cheng's method [62]. The tissue sucrose 
extraction was carried out according to Sonnewald's method [63], and the tissue sucrose contents determination was measured based on Stitt's description [63, 64].

\section{Determination of total ROS, histochemical staining and ROS scavenging enzyme activity assays}

Total reactive oxygen species (ROS) contents induced by internal $\mathrm{NH}_{4}{ }^{+}$excess were assessed by $2^{\prime}, 7^{\prime}$-Dichlorofluoresceindiacetate $\left(\mathrm{H}_{2} \mathrm{DCF}-\mathrm{DA}\right)$ method [65]. Fresh root or shoot samples were first made into single cell suspensions with single cell suspension medimachine after removing cell wall with cellulase and macerozyme. Then $\mathrm{H}_{2}$ DCF-DA was added to $200 \mu \mathrm{L}$ single cell suspensions to a final concentration of $10 \mu \mathrm{M}$, mixed and incubated at $37^{\circ} \mathrm{C}$ for $30 \mathrm{~min}$. Cells were pelleted by centrifugation at $1000 \mathrm{~g}$ for $10 \mathrm{~min}$, washed twice with PBS, and diluted with PBS for fluorescence assay. The absorbance was determined on a fluorescence microplate reader (BioTek Instruments, Winooski, VT) at an excitation wavelength of $500 \mathrm{~nm}$ and an emission wavelength of $530 \mathrm{~nm}$ according to the descriptions of Karlsson and Sun $[66,67]$.

Relatively uniformed and newly-grown roots and the second leaf of rice seedlings were used for histochemical staining [68]. The generation of hydrogen peroxide $\left(\mathrm{H}_{2} \mathrm{O}_{2}\right)$ or superoxide $\left(\mathrm{O}_{2}^{-}\right)$in situ was detected by using $3,3^{\prime}$-diaminobenzidine (DAB) or nitroblue tetrazolium (NBT) staining, respectively [68, 69]. Samples were analyzed and photographed using a fluorescence microscope (Nikon 80i). At least three leaves or roots were stained independently for these experiments.

For antioxidative enzyme activity analyses, $0.2 \mathrm{~g}$ of fresh root or shoot samples were ground in liquid $\mathrm{N}_{2}$, homogenized and crude extracts were used for the measurements of CAT, POD and SOD activities as previously described [32]. The specific activity of GST was assayed in the supernatant by following the increase of absorbance at $340 \mathrm{~nm}$ using GST Assay Kit according to the manufacturer instructions (CS0410, Sigma, USA). One unit of activity was defined as the amount of enzyme required to form $1 \mu \mathrm{M}$ product per minute at $30^{\circ} \mathrm{C}$. Enzyme activities were expressed as $\mathrm{U} . \mathrm{mg}^{-1} \mathrm{FW}$.

\section{Measurement of GS, GOGAT and Rubisco activities}

To prepare the crude enzyme extracts, roots or shoots of each sample were ground into fine powder with liquid $\mathrm{N}_{2}$ and homogenized with $50 \mathrm{mM}$ Tris- $\mathrm{HCl}$ buffer $(\mathrm{pH}$ 7.6, containing $10 \mathrm{mM} \mathrm{MgCl}, 1 \mathrm{mM}$ EDTA, $1 \mathrm{mM} \beta-$ mercaptoethanol and $4 \%(\mathrm{w} / \mathrm{v})$ polyvinylpolypyrrolidone-40) using a chilled pestle and mortar. The homogenate was centrifuged at $15000 \mathrm{~g}$ for $30 \mathrm{~min}$ at $4{ }^{\circ} \mathrm{C}$ and the supernatants were used for the determination of enzyme activities. The glutamine synthetase (GS) activity was measured according to Sakurai's description [70].
One unit of GS activity was expressed as the amount of enzyme catalyzing the formation of $1 \mu \mathrm{mol} \gamma$ glutamylhydroxamate per min at $37^{\circ} \mathrm{C}$ [71]. The glutamate synthase (GOGAT) activity in the supernatants was determined by the conversion of 2-ketoglutarate to glutamate in a reaction mixture containing $200 \mathrm{mM}$ $\mathrm{KH}_{2} \mathrm{PO}_{4}-\mathrm{KOH} \mathrm{pH} 7.5,10 \mathrm{mM}$ glutamine (Gln), $10 \mathrm{mM}$ 2-ketoglutarate, $0.14 \mathrm{mM} \mathrm{NADH}$ [72], One unit of GOGAT activity was defined as the oxidation rate of 1 nmol NADH per min at $30^{\circ} \mathrm{C}$. And the Rubisco activity was measured according to the method of $\mathrm{Li}$ [73]. One unit of Rubisco activity was defined as the oxidation rate of $1 \mathrm{nmol} \mathrm{NADH}$ per min at $25^{\circ} \mathrm{C}$.

\section{Statistical analysis}

Experiment data were expressed as means \pm S.E.M. of 3 independent replicates. Statistical differences were evaluated by Duncan's or t-test with SPSS 13.0 and the level of statistically significant difference was set at $\mathrm{p}<0.05$.

\section{Supplementary information}

Supplementary information accompanies this paper at https://doi.org/10. 1186/s12870-020-02363-x

Additional file 1: Figure S1. $\mathrm{H}_{2} \mathrm{O}_{2}$ localization in situ.

Additional file 2: Figure S2. $\mathrm{O}_{2}^{-}$localization in situ.

Additional file 3: Figure S3. Free amino acid contents assays.

Additional file 4: Table S1. Summary of total DEGs identifided in rice roots and shoots following a $4 \mathrm{~h}$ rapid $\mathrm{NH}_{4}{ }^{+}$accumulation treatment.

Additional file 5: Table S2. GO enrichment analysis of DEGsin rice roots and shoots following a $4 \mathrm{~h}$ rapid $\mathrm{NH}_{4}{ }^{+}$accumulation treatment. (XLS 192 kb)

Additional file 6: Table S3. KEGG Enrichment Analysis of DEGsin rice roots and shoots following a $4 \mathrm{~h}$ rapid $\mathrm{NH}_{4}{ }^{+}$accumulation treatment. (XLS 56 kb)

Additional file 7: Table S4. The sequences of primers used for realtime RT-PCR in this research (XLS $27 \mathrm{~kb}$ )

\section{Abbreviations}

AMT: Ammonium transporter; CAT: Catalase; $\mathrm{CO}_{2}$ : Carbon dioxide; DAB: 3,3' diaminobenzidine; DEGs: Differentially Expressed Genes; GABA: GammaAminobutyric acid; GO: Gene Ontology; KEGG: Kyoto Encyclopedia of Genes and Genomes; GOGAT: Glutamate synthase; GS: Glutamine synthetase; GSH: Glutathione; GST: Glutathione S-transferase; H2DCF-DA: 2',7'-

Dichlorofluoresceindiacetate; $\mathrm{H}_{2} \mathrm{O}_{2}$ : Hydrogen peroxide; LHCs: Lightharvesting complexes; MSX: L-methionine-D,L-sulfoximine; N: Nitrogen; NBT: Nitroblue tetrazolium; $\mathrm{NH}_{4}^{+}$: Ammonium; qRT-PCR: Quantitative Reverse Transcription Polymerase Chain Reaction; $\mathrm{O}_{2}^{-}$: Superoxide; POD: Peroxidase; ROS: Reactive Oxygen Species; RNA-Seq: RNA sequencing;

SOD: Superoxide dismutase; Rubisco: Ribulose-1,5-bisphosphate carboxylase/oxygenase; TCA cycle: Tricarboxylic acid cycle

\section{Acknowledgements}

We thank Ms. Rong Huang and Mr. Zuohao Ma, Analytical and Testing Center, Institute of Soil Science (Nanjing), Chinese Academy of Sciences for kind help and technical assistant.

Authors' contributions

YS and SY conceived and designed the research. SY, DH, MJ prepared samples for RNA-Seq analysis, performed quantitative PCR validation and analyzed data. SY, DH, MJ, YL, ZL, YH and TC carried out physiological/ 
biochemical assays and data analyses. SY and YS wrote the manuscript. All authors read and approved the manuscript.

\section{Funding}

This work was supported by the National Key Research \& Development Program of China (2017YFD0200100, 2017YFD0200103), the National Science Foundation of China (Grant Nos. 31501826, 31701991) and the Project of Priority and Key Areas, ISSCAS (ISSASIP1609). The funders did not play any roles in the design of the study, collection, analysis and interpretation of the relevant data, and writing the manuscript.

\section{Availability of data and materials}

All data supporting the conclusions of this article are provided within the article (and its additional files).

\section{Ethics approval and consent to participate}

Not applicable.

\section{Consent for publication}

Not applicable.

\section{Competing interests}

The authors declare that they have no competing interests.

\section{Author details}

${ }^{1}$ State Key Laboratory of Soil and Sustainable Agriculture, Institute of Soil Science, Chinese Academy of Sciences, No. 71, East Beijing Road, Nanjing 210008, China. ${ }^{2}$ University of Chinese Academy of Sciences, Beijing 100049, China.

Received: 27 October 2019 Accepted: 25 March 2020

Published online: 07 April 2020

\section{References}

1. Aerts RC, Chapin FS III. The mineral nutrition of wild plants revisited: a reevaluation of processes and patterns. Adv Ecol Res. 1999;30:1-67.

2. Schlegel AJ, Grant CA, Havlin JL. Challenging approaches to NitrogenFertilizer recommendations in continuous cropping Systems in the Great Plains. Agron J. 2005;97:391-8.

3. Kant S, Bi YM, Rothstein SJ. Understanding plant response to nitrogen limitation for the improvement of crop nitrogen use efficiency. J Exp Bot. 2011;62:1499-509.

4. Makino A. Photosynthesis, grain yield, and nitrogen utilization in rice andwheat. Plant Physiol. 2011;155:125-9.

5. Tabuchi M, Abiko T, Yamaya T. Assimilation of ammonium ions and reutilization of nitrogen in rice (Oryza sativa L.). J Exp Bot. 2007;58:2319-27.

6. Chen YZ, Murchie EH, Hubbart S, Horton P, Peng SB. Effect of seasondependent irradiance levels and nitrogen-deficiency on phytosynthesis and photoinhibition in field-grown rice. Physiol Plant. 2003;117:343-51.

7. Dobermann A,Fairhurst T. Rice Nutrient Disorders\&Nutrient Management. 2000;pp:41-60. Potash \&Phosphate Institute (PPI), Potash \& Phosphate Institute of Canada (PPIC) and International Rice Research Institute (IRRI).

8. Reich PB, Hobbie SE, Lee T, Ellsworth DS, West JB, Tilman D, Knops JMH, Naeem S, Trost J. Nitrogen limitation constrains sustainability of ecosystem response to $\mathrm{CO}_{2}$. Nature. 2006;440:922-5.

9. $\quad$ Zhang YM, Yan YS, Wang LN, Yang K, Xiao N, Liu YF, Fu YP, Sun ZX, Fang $R X$, Chen $X Y$. A novel rice gene, NRR responds to macronutrient deficiency and regulates root growth. Mol Plant. 2012;5:63-72.

10. Peng SB, Buresh RJ, Huang JL, Zhong XH, Zou YB, Yang JC, Wang GH, Liu YY, Hu HR, Tang QY, Cui KH, Zhang FS, Dobermann A. Improving nitrogen fertilization in rice by site-specific N management. Agron Sustain Dev. 2010; 2:943-52.

11. Yuan LP. Progress in super-hybrid rice breeding. Crop J. 2017:5(2):100-2.

12. Ju CX, Buresh RJ, Wang ZQ, Zhang H, Liu LJ, Yang JC, Zhang JH. Root and shoot traits for rice varieties with higher grain yield and higher nitrogen use efficiency at lower nitrogen rates application. Field Crop Res. 2015;175:4755.

13. Li Q, Li BH, Kronzucker HJ, Shi WM. Root growth inhibition by $\mathrm{NH}_{4}{ }^{+}$in Arabidopsis is mediated by the root tip and is linked to $\mathrm{NH}_{4}^{+}$efflux and GMPase activity. Plant Cell Environ. 2010;33:1529-42.
14. Li BH, Li Q, Su YH, Chen H, Xiong LM, Mi GH, Kronzucker HJ, Shi WM. Shootsupplied ammonium targets the root auxin influx carrier AUX1 and inhibits lateral root emergence in Arabidopsis. Plant Cell Environ. 2011;34:933-46.

15. Hirano T, Satoh Y, Ohki A, Takada R, Arai T, Michiyama H. Inhibition of ammonium assimilation restores elongation of seminal rice roots repressed by high levels of exogenous ammonium. Physiol Plant. 2008;134:183-90.

16. Ranathunge K, El-Kereamy A, Gidda S, Bi Y, Rothstein S. AMT1;1 transgenic rice plants with enhanced $\mathrm{NH}_{4}^{+}$permeability show superior growth and higher yield under optimal and suboptimal $\mathrm{NH}_{4}{ }^{+}$conditions. J Exp Bot. 2014;65:965-79.

17. Ranathunge K, Schreiber L, Bi YM,Rothstein SJ. Ammonium-induced architectural and anatomical changes with altered suberin and lignin levels significantly change water and solute permeabilities of rice (Oryza sativa L.) roots. Planta. 2016;243:231-249.

18. Xie YJ, Mao Y, Xu S, Zhou H, Duan XL, Cui WT, Zhang J, Xu GH. Heme-heme oxygenase 1 system is involved in ammonium tolerance by regulating antioxidant defence in Oryza sativa. Plant Cell Environ. 2015:38:129-43.

19. Sun L, Di DW, Li GJ, Kronzucker HJ, Shi WM. Spatio-temporal dynamics in global rice gene expression (Oryza sativa L.) in response to high ammonium stress. J Plant Physiol. 2017;212:94-104.

20. Britto DT, Kronzucker $\mathrm{HJ} . \mathrm{NH}_{4}{ }^{+}$toxicity in higher plants: a critical review. J Plant Physiol. 2002;159:567-84.

21. Li BH, Li GJ, Kronzucker HJ, Baluska F, Shi WM. Ammonium stress in Arabidopsis: signaling, genetic loci, and physiological targets. Trends Plant Sci. 2014;19:107-14.

22. Bittsánszky A, Pilinszky K, Gyulai G, Komives T. Overcoming ammonium toxicity. Plant Sci. 2015;231:184-90.

23. Esteban R, Ariz I, Cruz C, Moran JF. Review: mechanisms of ammonium toxicity and the quest for tolerance. Plant Sci. 2016;248:92-101.

24. Liu Y, Von Wirén N. Ammonium as a signal for physiological and morphological responses in plants. J Exp Bot. 2017;68(10):2581-92.

25. Qin C, Qian WQ, Wang WF, Wu Y, Yu CM, Jiang XH, Wang DW, Wu P. GDPmannose pyrophosphorylase is a genetic determinant of ammonium sensitivity in Arabidopsis thaliana. Proc Natl Acad Sci U S A. 2008;105:1830813.

26. Barth C, Gouzd Z, Steele H, Imperio R. A mutation in GDP-mannose pyrophosphorylase causes conditional hypersensitivity to ammonium, resulting in Arabidopsis root growth inhibition, altered ammonium metabolism, and hormone homeostasis. J Exp Bot. 2010;61(2):379-94.

27. Jadid N, Mialoundama AS, Heintz D, Ayoub D, Erhardt M, Mutterer J, Meyer D, Alioua A, Van Dorsselaer A, Rahier A, Camara B, Bouvier F. Dolichol phosphate mannose synthase 1 mediates the biogenesis of isoprenyl-linked glycans and influences development, stress response, and ammonium hypersensitivity in Arabidopsis. Plant Cell. 2011;23:1985-2005.

28. Li BH, Li Q, Xiong LM, Kronzucker HJ, Kramer U, Shi WM. Arabidopsis plastid AMOS1/EGY1 integrates abscisic acid signaling to regulate global gene expression response to ammonium stress. Plant Physiol. 2012;160:2040-51.

29. Yang SY, Hao DL, Song ZZ, Yang GZ, Wang L, Su YH. RNA-Seq analysis of differentially expressed genes in rice under varied nitrogen supplies. Gene. 2015;555(2):305-17.

30. Ma XL, Zhu CH, Yang N, Gan LJ, Xia K. -Aminobutyric acid addition alleviates ammonium toxicity by limiting ammonium accumulation in rice (Oryza sativa) seedlings. Physiol Plant. 2016:158:389-401.

31. Fan XR, Xie D, Chen JG, Lu HY, Xu YL, Ma C, Xu GH. Over-expression of OsPTR6 in rice increased plant growth at different nitrogen supplies but decreased nitrogen use efficiency at high ammonium supply. Plant Sci. 2014:227:1-11.

32. Jin M, Guo MY, Yue GZ, Li JL, Yang SY, Zhao PS, Su YH. An unusual strategy of stomatal control in the desert shrub Ammopiptanthus mongolicus. Plant Physiol Biochem. 2018;125:13-26.

33. Mittler R. Oxidative stress, antioxidants and stress tolerance. Trends Plant Sci. 2002:7(9):405-10.

34. Thalmann M, Santelia D. Starch as a determinant of plant fitness under abiotic stress. New Phytol. 2017:214:943-51.

35. Sieciechowicz KA, Joy KW, Ireland RJ. Effect of methionine Sulfoximine on Asparaginase activity and ammonium levels in pea leaves. Plant Physiol. 1989;89:192-6

36. Shigeto J, Tsutsumi Y. Diverse functions and reactions of class III peroxidases. New Phytol. 2016;209:1395-402.

37. Pietrzykowska M, Suorsa M, Semchonok DA, Tikkanen M, Boekema EJ, Aro EM, Jansson S. The light-harvesting chlorophyll $a / b$ binding proteins Lhcb1 
and Lhcb2 play complementary roles during state transitions in Arabidopsis. Plant Cell. 2016;26(9):3646-60.

38. Sui B, Feng XM, Tian GL, Hu XY, Shen QR, Guo SW. Optimizing nitrogen supply increases rice yield and nitrogen use efficiency by regulating yield formation factors. Field Crop Res. 2013;150:99-107.

39. Zhang FS, Chen XP, Vitousek P. An experiment for the world: China's scientists are using a variety of approaches to boost crop yields and limit environmental damage. Nature. 2013;497:33-5.

40. Zhu YY, Di TJ, Xu GH, Chen X, Zeng HQ, Yan F, Shen QR. Adaptation of plasma membrane $\mathrm{H}^{+}$-ATPase of rice roots to low $\mathrm{pH}$ as related to ammonium nutrition. Plant Cell Environ. 2009;32(10):1428-40.

41. Btritto DT, Siddiqi MY, Glass ADM, Kronzucker HJ. Futile transmembrane $\mathrm{NH}_{4}^{+}$cycling: a cellular hypothesis to explain ammonium toxicity in plants. Proc Natl Acad Sci U S A. 2001;98(7):4255-8.

42. Skopelitis DS, Paranychianakis NV, Paschalidis KA, Pliakonis ED, Delis ID, Yakoumakis DI, Kouvarakis A, Papadakis AK, Stephanou EG, RoubelakisAngelakis KA. Abiotic stress generates ROS that signal expression of anionic glutamate dehydrogenases to form glutamate for Proline synthesis in tobacco and grapevine. Plant Cell. 2006;18:2767-81.

43. Nimptsch J, Pflugmacher S. Ammonia triggers the promotion of oxidative stress in the aquatic macrophyte Myriophyllum mattogrossense. Chemosphere. 2007;66:708-14.

44. Patterson K, Cakmak T, Cooper A, Lager I, Rasmusson AG, Escobar MA. Distinct signalling pathways and transcriptome response signatures differentiate ammonium-and nitrate-supplied plants. Plant Cell Environ. 2010:33:1486-501.

45. Lemoine R, Camera SL, Atanassova R, Dedaldechamp F, Allario T, Pourtau N, Bonnemain JL, Laloi M, Coutos-Thevenot P, Maurousset L, Faucher M, Girousse C, Lemonnier P, Parrilla J, Durand M. Source-to-sink transport of sugar and regulation by environmental factors. Front Plant Sci. 2013:4:272

46. Li Y, Zhou JY, Hao DL, Yang SY, Su YH. Arabidopsis under ammonium oversupply: characteristics of ammonium toxicity in relation to the activity of ammonium transporters. Pedosphere. 2020;30(2):1-12.

47. Qiu ZB, Wang YF, Zhu AJ, Peng FL, Wang LS. Exogenous sucrose can enhance tolerance of Arabidopsis thaliana seedlings to salt stress. Biol Plantarum. 2014;58(4):611-7.

48. Hammad A, Khan HA, Siddique KHM, Colmer TD. Vegetative and reproductive growth of salt-stressed chickpea are carbon-limited: sucrose infusion at the reproductive stage improves salt tolerance. J Exp Bot. 2017 68(8):2001-11.

49. Ainsworth EA, Long SP. What have we learned from 15 years of free-air $\mathrm{CO}_{2}$ enrichment (FACE)? A meta-analytic review of the responses of photosynthesis, canopy properties and plant production to rising $\mathrm{CO}_{2}$. New Phytol. 2005;165:351-72.

50. Becker $\mathrm{C}$, Kläring $\mathrm{HP} . \mathrm{CO}_{2}$ enrichment can produce high red leaf lettuce yield while increasing most flavonoid glycoside and some caffeic acid derivative concentrations. Food Chem. 2016;199:736-45.

51. Kimball BA. Crop responses to elevated $\mathrm{CO}_{2}$ and interactions with $\mathrm{H}_{2} \mathrm{O}, \mathrm{N}$, and temperature. Curr Opin Plant Bio. 2016;31:36-43.

52. Leakey ADB, Ainsworth EA, Bernacchi CJ, Rogers A, Long SP, Ort DR Elevated $\mathrm{CO}_{2}$ effects on plant carbon, nitrogen, and water relations: six important lessons from FACE. J Exp Bot. 2009;60:2859-76.

53. Seneweera SP, Conroy JP, Ishimaru K, Ghannoum O, Okada M, Lieffering M, Kim HY, a Kobayashi K. Changes in source-sink relations during development influence photosynthetic acclimation of rice to free air $\mathrm{CO}_{2}$ enrichment (FACE). Funct Plant Biol 2002;29:945-953.

54. Stitt M, Krapp A. The interaction between elevated carbon dioxide and nitrogen nutrition: the physiological and molecular background. Plant Cell Environ. 1999:22:583-621

55. Roosta HR, Schjoerring JK. Root carbon enrichment alleviates ammonium toxicity in cucumber plants. J Plant Nutr. 2008:31:941-58.

56. Wang MY, Siddiqi MY, Ruth TJ, Glass ADM. Ammonium uptake by rice roots. II. Kinetics of ${ }^{13} \mathrm{NH}_{4}{ }^{+}$in flux across the plasmalemma. Plant Physiol. 1993; 103:1259-67.

57. Sonoda Y, Ikeda A, Saiki S, Yamaya T, Yamaguchi J. Feedback regulation of the ammonium transporter gene family AMT1 by glutamine in rice. Plant Cell Physiol. 2003;44:1396-402.

58. Yang SY, Hao DL, Cong Y, Jin M, Su YH. The rice OsAMT1;1 is a protonindependent feedback regulated ammonium transporter. Plant Cell Rep. 2015b:34:321-30.
59. Lejay L, Tillard P, Lepetit M, Olive FD, Filleur S, Daniel-Vedele F, Gojon A. Molecular and functional regulation of two NO3- uptake systems by $\mathrm{N}$ - and C-status of Arabidopsis plants. Plant J. 1999;18(5):509-19.

60. WeatherburnW. Phenol-hypochlorite reaction for determination of Ammonia. Anal Chem 1967;39(8):971-974.

61. Yang ZM, Guo RB, Xu XH, Fan XL, Li XP. Enhanced hydrogen production from lipid-extracted microalgal biomass residues through pretreatment. Int J Hydrogen Energ. 2010;35:9618-23.

62. Cheng MC, Ko K, Chang WL, Kuo WC, Chen GH, Lin TP. Increased glutathione contributes to stress tolerance and global translational changes in Arabidopsis. Plant J. 2015;83:926-39.

63. Sonnewald U, Braue M, von Schaewen A, Stitt M, Willmitzer L. Transgenic tobacco plants expressing yeast-derived invertase in either the cytosol, vacuole or apoplast: a powerful tool for studying sucrose metabolism and sinkkource interactions. Plant J. 1991:1(1):95-106.

64. Stitt M, Lilley RMC, Gerhardt R, Heldt HW. Determination of metabolite levels in specific cells and subcellular compartments of plant leaves. Methods Enzymol. 1989;174:518-52.

65. Jambunathan N. Determination and detection of reactive oxygen species (ROS), lipid peroxidation, and electrolyte leakage in plants. Plant Stress Tolerance, Methods in Molecular Biology, 2010;pp:291-297. Springer Science, Business Media, LLC

66. Karlsson M, Kurz T, Brunk UT, Nilsson SE, Frennesson Cl. What does the commonly used DCF test for oxidative stress really show? Biochem J. 2010; 428:183-90

67. Sun $L$, Zhang $J B, L u X Y$, Zhang $L Y$, Zhang YL. Evaluation to the antioxidant activity of total flavonoids extract from persimmon (Diospyros kaki L.) leaves. Food Chem Toxicol. 2011;49:2689-96.

68. Kuar N, Sharma I, Kirat K, Pati PK. Detection of reactive oxygen species in Oryza sativa L. (Rice). Bio-Protocol. 2016;6(24):1-9.

69. Yang YN, Qi M, Mei CS. Endogenous salicylic acid protects rice plants from oxidative damage caused by aging as well as biotic and abiotic stress. Plant J. 2004:40:909-19.

70. Sakurai N, Hayakawa T, Nakamura T, Yamaya T. Changes in the cellular localization of cytosolic glutamine synthetase protein in vascular bundles of rice leaves at various stages of development. Planta. 1996;200:306-11.

71. Lin $\mathrm{YL}$, Chao $\mathrm{YY}$, Kao CH. Exposure of rice seedlings to heat shock protects against subsequent $\mathrm{cd}$-induced decrease in glutamine synthetase activity and increase in specific protease activity in leaves. J Plant Physiol. 2010;167: $1061-5$.

72. Shah JM, Bukhari SAH, Zeng J, Quan X, Ali E, Muhammad N, Zhang G. Nitrogen ( $\mathrm{N}$ ) metabolism related enzyme activities, cell ultrastructure and nutrient contents as affected by $\mathrm{N}$ level and barley genotype. J Integr Agr. 2017:16(1):190-8.

73. Li Y, Ren BB, Ding L, Shen QR, Peng SB, Guo SW. Does chloroplast size influence photosynthetic nitrogen use efficiency? PLoS One. 2013;8(4): e62036.

\section{Publisher's Note}

Springer Nature remains neutral with regard to jurisdictional claims in published maps and institutional affiliations.

Ready to submit your research? Choose BMC and benefit from:

- fast, convenient online submission

- thorough peer review by experienced researchers in your field

- rapid publication on acceptance

- support for research data, including large and complex data types

- gold Open Access which fosters wider collaboration and increased citations

- maximum visibility for your research: over $100 \mathrm{M}$ website views per year

At $\mathrm{BMC}$, research is always in progress.

Learn more biomedcentral.com/submission 